\title{
Novel glitazones as PPAR $\gamma$ agonists: molecular design, synthesis, glucose uptake activity and 3D QSAR studies
}

\author{
Subhankar P. Mandal' ${ }^{1}$ Aakriti Garg' ${ }^{1}$, P. Prabitha' ${ }^{1}$, Ashish D. Wadhwani' ${ }^{2}$ Laxmi Adhikary ${ }^{3}$ \\ and B. R. Prashantha Kumar ${ }^{1 *}$ (D)
}

\begin{abstract}
Background: An alarming requirement for finding newer antidiabetic glitazones as agonists to PPARy are on its utmost need from past few years as the side effects associated with the available drug therapy is dreadful. In this context, herein, we have made an attempt to develop some novel glitazones as PPARy agonists, by rational and computer aided drug design approach by implementing the principles of bioisosterism. The designed glitazones are scored for similarity with the developed 3D pharmacophore model and subjected for docking studies against PPARy proteins. Synthesized by adopting appropriate synthetic methodology and evaluated for in vitro cytotoxicity and glucose uptake assay. Illustrations about the molecular design of glitazones, synthesis, analysis, glucose uptake activity and SAR via 3D QSAR studies are reported.

Results: The computationally designed and synthesized ligands such as 2-(4-((substituted phenylimino)methyl) phenoxy)acetic acid derivatives were analysed by IR, ${ }^{1} \mathrm{H}-\mathrm{NMR},{ }^{13} \mathrm{C}-\mathrm{NMR}$ and MS-spectral techniques. The synthesized compounds were evaluated for their in vitro cytotoxicity and glucose uptake assay on 3T3-L1 and L6 cells. Further the activity data was used to develop 3D QSAR model to establish structure activity relationships for glucose uptake activity via CoMSIA studies.
\end{abstract}

Conclusion: The results of pharmacophore, molecular docking study and in vitro evaluation of synthesized compounds were found to be in good correlation. Specifically, CPD03, 07, 08, 18, 19, 21 and 24 are the candidate glitazones exhibited significant glucose uptake activity. 3D-QSAR model revealed the scope for possible further modifications as part of optimisation to find potent anti-diabetic agents.

Keywords: PPARy, Pharmacophore, Molecular docking, Glucose uptake assay, 3D-QSAR, CoMSIA

\section{Introduction}

Type 2 Diabetes mellitusis a heterogeneous group of disorders linked to the inability to regulate glucose metabolism. Unfortunately, incidence in individuals is increasing with respect to time [1]. The prevalence of diabetes increases with age and currently affects one-fifth of the world's population [2,3]. The mechanism by which the complications of the affected patient's increases is

\footnotetext{
*Correspondence: brprashanthkumar@jssuni.edu.in

${ }^{1}$ Department of Pharmaceutical Chemistry, JSS College of Pharmacy, JSS

Academy of Higher Education and Research, Mysuru 570 015, India

Full list of author information is available at the end of the article
}

still unknown, but the most commonly accepted hypothesis is that, Type 2 Diabetes is multifactorial which includes both genetic and environmental elements that affects tissue insulin sensitivity and beta-cell functions. Although it is generally agreed that both has significant roles in plasma glucose regulation, however, the interlinking mechanisms controlling these two impairment is still unknown $[4,5]$.

Transcription factors such as Peroxisome Proliferator Activated Receptors (PPARs) has been extensively studied and reported for its metabolic functions, which belongs to the nuclear receptor superfamily, whose members possess selectivity towards lipophilic ligands and 
transduce chemical signals into specific changes in gene expression [6, 7]. There are three PPAR subtypes, as PPAR $\alpha, \operatorname{PPAR} \beta / \delta$, and PPAR $\gamma$; they are closely connected factors which control the midway metabolism of glucose and lipid homeostasis, adipogenesis, immune response, cell growth and differentiation [8, 9]. Out of all, agonistic activation of PPAR $\gamma$ can efficiently regulate plasma glucose level; hence can control Type 2 Diabetes [10].

It is very astounding to notice that in last few decades development of antidiabetic drugs was very profound, and drugs approved by USFDA is gigantic in number, hence there is a persistent need in innovative development of novel antidiabetic drugs [11, 12]. In past, several attempts were made to identify agents with thiazolidinedione, oxazolidinedione, tetrazole, oxathiadiazol and $\alpha$-alkoxy carboxylic acid derivatives but none of them showed optimum desired activity. Several PPAR $\gamma$ agonists (Glitazones) have been developed (Fig. 1) [13], most explicitly thiazolidinediones, a well-known member of glitazone family were studied and widely used for the above purposes, however, they show some side effects besides being pharmacologically active [14]. Glitazones such as ragaglitazar, MK-0767, aleglitazar and naveglitazar, just to name a few, have exhibited clinical utility to glycaemic control and insulin sensitivity but also found to be associated with an increased incidence of both bladder cancer and hyperplasia in rodent studies [15].

Considering the various side effects associated with thiazolidinedione ring, bioisosteric replacement of the ring alongside keeping other structural features intact, such as, aromatic trunk, hetero atom spacer and hydrophobic tail may possibly good (Fig. 2) for antidiabetic, lipid lowering and anti-cancer activities [15-21].

In light of above facts, in the present study, we performed 3D pharmacophore search, molecular docking and dynamics, synthesis and anti-hyperglycemic (glucose uptake) studies on novel glitazones of phenoxy acetic acid derivatives.

\section{Results and discussion Pharmacophore design studies}

Pharmacophore based drug design approaches are one of the important tools in drug discovery. Various ligandbased and structure-based virtual screening protocols adopt pharmacophore modelling [22]. Considering importance of pharmacophore in rational drug design, we made an attempt to develop structure-based pharmacophore from PPAR-glitazone bound protein complex by generating pharmacophoric QUERY (Fig. 3). The built QUERY was searched against a dataset of rationally designed glitazones (2234 glitazones), designed from different possible substituent combinations, keeping common structural scaffold intact. For validation of built pharmacophore model, the Güner-Henry (GH) [23] scoring method was adopted, where a decoy set of 1724 molecules were also screened against the built QUERY. Finally, the statistical parameters such as, \%AD, \%AE, \%Y, $\mathrm{E}$ and $\mathrm{GH}$ were calculated. All the manually designed glitazars along with reference pioglitazone were searched against the 3D pharmacophore QUERY. The \% similarity (QFIT) of higher ranked compounds amongst the database searched are as shown in Table 1. The validation of search operation was evaluated by analysing the statistical parametersas shown in Table 2 for the number of hits generated.

The 3D pharmacophore based search operation identified the possible hits among the whole dataset by considering QUERY structural features. The QFIT value of pioglitazone was found to be highest among all because the QUERY was generated from the proteinbound to pioglitazone as reference ligand; this eventually reflects the quality of pharmacophore model. The database search identified CPD03, 07, 08, 19 and 21 as possible hits among the whole dataset of glitazones. The statistical parameters such as \% AD, \% Y, \% AH, $\mathrm{E}$ and $\mathrm{GH}$ represents the quality of pharmacophore model, especially the GH score between 6 to 10 indicates good pharmacophore model thereby its enhanced predictability.

\section{Docking study}

Molecular docking studies virtually defines the binding modes of ligand interaction at the active site of the receptor [24]. Therefore, top 24 hits from the pharmacophore search operation were subjected for docking studies against PPAR $\gamma$, as part of structure based virtual screening. We performed molecular docking study on the target protein and result is as depicted in Table 3. To validate the docking protocol co-crystalized ligand was checked by re-docking before and after the docking operation [25]. Pioglitazone along with other designed compounds made to bind to the active site of the PPAR $\gamma$ protein. As part of binding interactions with glitazones, important amino acids, such as, His 323, His 449, Tyr 473, Ser 289 and Gln 286 are interacting residues for PPAR respectively (Fig. 4 and Fig. 5), with Hydrogen bond distances ranged between 2.089 to $3.278 \AA$.

\section{Molecular dynamic simulation studies}

Molecular dynamic (MD) simulation studies is ideal to perform after the docking studies to understand the dynamic behaviour of the protein-ligand complex conformationsin order to mimic the behaviour in actual environment [26]. It provides detailed information on the motion of whole molecule as well as individual 

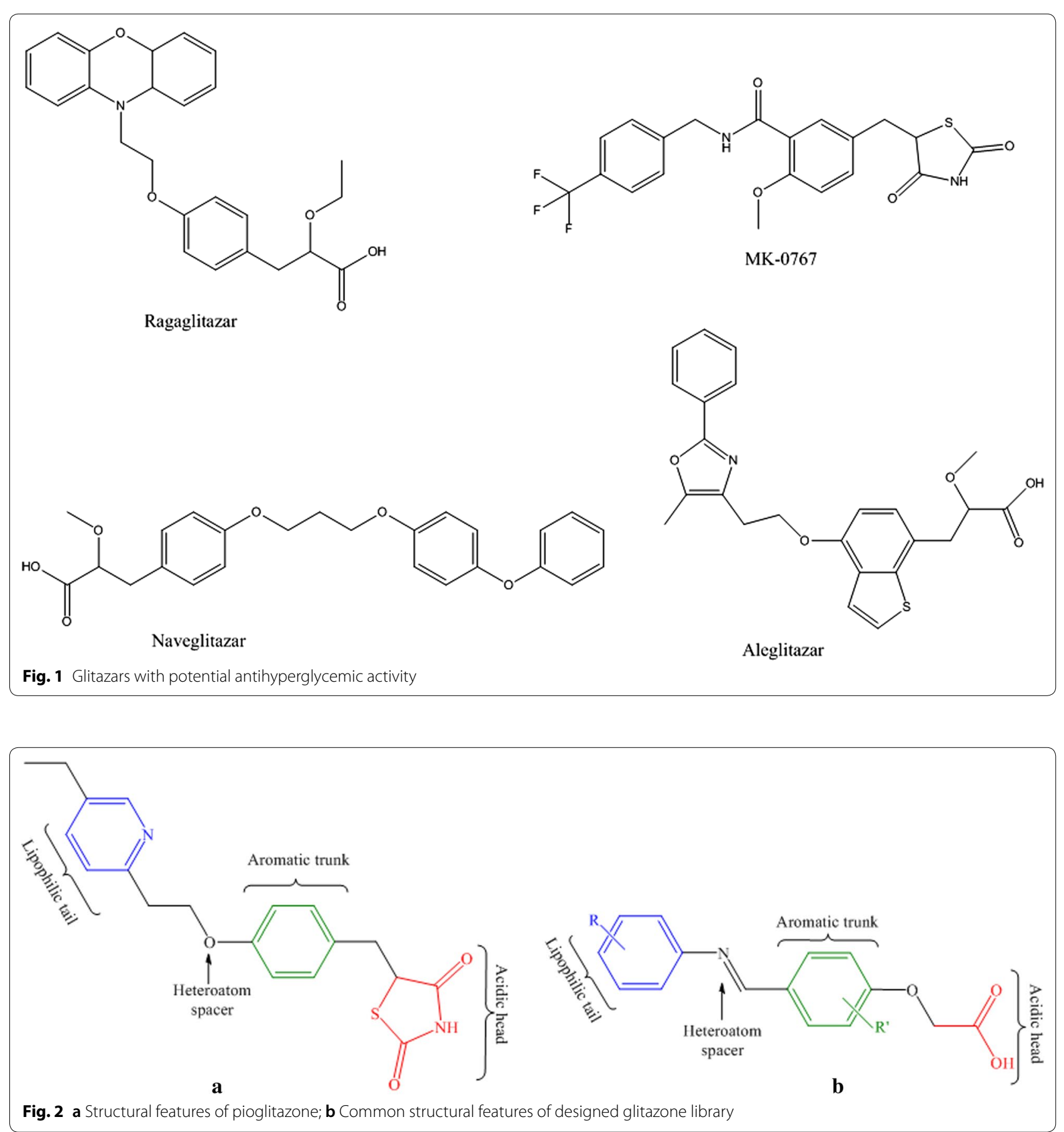

atoms as a function of time and thereby provides valuable information between them [27]. In this context, we performed MD simulation to understand the binding affinities of different ligands (reference ligand, CPD07, and CPD21) with PPAR $\gamma$ protein in its free and in the form of complex. To make a comparative understanding of the dynamic behavior of our designed ligands with the target proteins, we took reference ligand whose stability with the proteins in the complex is well known. We have analysed root mean square deviation (RMSD), root mean square fluctuation (RMSF), radius of gyration $(\mathrm{Rg})$, solvent accessible surface area (SASA), number of hydrogen bonds, and variation of secondary structure pattern between the protein and their complexes (PPAR $\gamma$ with reference ligand, CPD07 and CPD21). Four independent simulations were carried out for 


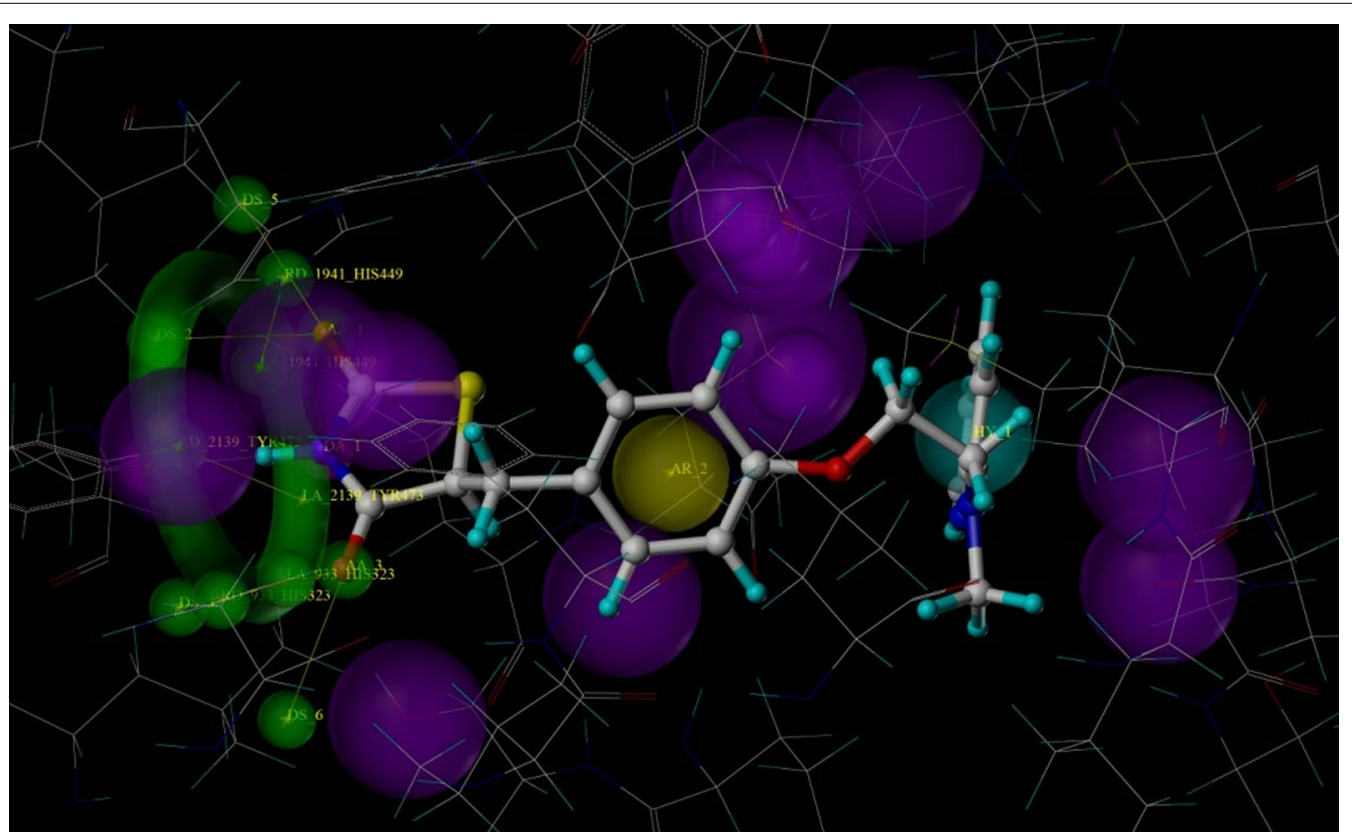

Fig. 3 Pharmacophoric QUERY built from protein ligand complex, where green representing hydrogen bond acceptor (0.5 $\AA$ tolerance), magenta representing hydrogen bond donor ( $0.5 \AA$ Åtolerance) and also neighbouring amino acids ( $1.0 \AA$ tolerance), yellow representing aromatic ring ( $1.0 \AA$ tolerance) and cyan representing hydrophobic ring (1.0 ^ tolerance)

\section{Table 1 QFIT scores of the designed glitazones}

\begin{tabular}{llllll}
\hline Sl. no. & Compound & QFIT & Sl.no. & Compound & QFIT \\
\hline 1. & Pioglitazone & 96.24 & 14 & CPD16 & 61.56 \\
2. & CPD19 & 86.45 & 15 & CPD24 & 60.30 \\
3. & CPD07 & 86.45 & 16 & CPD22 & 60.00 \\
4. & CPD21 & 86.45 & 17 & CPD10 & 58.29 \\
5. & CPD03 & 85.31 & 18 & CPD13 & 58.02 \\
6. & CPD20 & 85.12 & 19 & CPD23 & 55.03 \\
7. & CPD08 & 85.06 & 20 & CPD17 & 54.67 \\
8. & CPD14 & 81.29 & 21 & CPD09 & 54.67 \\
9. & CPD12 & 74.24 & 22 & CPD15 & 52.33 \\
10. & CPD11 & 74.24 & 23 & CPD06 & 52.33 \\
11. & CPD04 & 74.24 & 24 & CPD02 & 50.45 \\
12. & CPD05 & 68.29 & 25 & CPD01 & 50.45 \\
13. & CPD18 & 61.56 & - & - & - \\
\hline
\end{tabular}

To validate the derived pharmacophore model decoy set of 1724 molecules from ZINC databasewere searched against built pharmacophore QUERY. Finally the number of hits was calculated by considering the QFIT > 50

Number of hits $\left(\mathrm{H}_{\mathrm{a}}\right)$ obtained from active dataset $=24$

Number of hits $\left(\mathrm{H}_{\mathrm{d}}\right)$ obtained from decoy dataset $=12$

Number of actives $(A)=2234$, number of decoy $(D)=1724$

the native protein structure along with their respective complexes for 5 ns simulation time. We found that the protein, PPAR $\gamma$, in its free and complex form reach equilibrium approximately at 2 ns of time and then after showing stable trajectory and resonates only between
0.10 to $0.25 \mathrm{~nm}$ of RMSD till the end of the remaining simulation (Fig. 6a), it's been clear from the RMSD plot that PPARY is quite flexible in its free form and deviating in reasonably higher RMSD values than its complex forms (Fig. 6a), led to the conclusion that the complex formation influenced changes in the flexibility of the dynamic behavior of the protein. We have also observed that CPD21 in its complex with protein have very narrow RMSD value $(0.15-0.20 \mathrm{~nm})$, hence predicted to form stable complexes till the end of the simulation. Similarly, we have observed that CPD07 with the protein showed similar trajectories but minimal deviations were observed from the perspective of equilibration time and average RMSD values, although attaining final stable equilibration through to the end of the simulation. All the complexes throughout the simulation tend to reach a stable trajectory. The higher RMSD obtained for all complexes limited to $0.3 \mathrm{~nm}$ exhibits that the simulations produced stable trajectories and delivered an appropriate root for further investigation.

The radius of gyration calculates the mass weighted root mean square distance of atoms from their respective centre of mass. The overall structures at various time points during the trajectory can be analysed for capability, shape and folding in the plot of $R_{g}$ (Fig. 6b). Throughout the simulation, all the proteins and their complexes exhibited a similar pattern for the $R_{g}$ value, at which $R_{g}$ score for PPAR $\gamma$ group ranges at higher value of $1.95-2.00 \mathrm{~nm}$. 
Table 2 Statistical parameters of pharmacophore study

\begin{tabular}{lll}
\hline SI no. & Statistical parameters & Value obtained \\
\hline 1. & $\%$ AD (percentage of actives in the dataset) & $1.43 \%$ \\
2. & $\%$ Y (percentage of actives in total hits) & $45.45 \%$ \\
3. & $\%$ AH (percentage of actives returned as hits) & $40 \%$ \\
4. & E (enrichment factor by which results are & 31.78 \\
& richer in actives than dataset) & 6.12 \\
5. & GH (Güner-Henry) score & \\
\hline
\end{tabular}

Table 3 Docking scores of compounds with respect
to PPARy protein

\begin{tabular}{|c|c|c|c|c|}
\hline SI. no. & Compound & Total score & Crash score & Polar score \\
\hline 1. & CPD19 & 7.7081 & -1.3004 & 2.3039 \\
\hline 2. & CPD20 & 7.5315 & -0.5913 & 5.4173 \\
\hline 3. & CPD22 & 7.3343 & -1.6674 & 4.0673 \\
\hline 4. & CPD07 & 7.2051 & -1.9381 & 4.7489 \\
\hline 5. & CPD14 & 7.8855 & -1.6489 & 3.761 \\
\hline 6. & Pioglitazone & 7.7679 & -0.692 & 5.0003 \\
\hline 7. & CPD24 & 7.7392 & -0.5356 & 3.7936 \\
\hline 8. & CPD15 & 7.6704 & -0.4739 & 4.1586 \\
\hline 9. & CPD13 & 7.6558 & -0.6428 & 3.1524 \\
\hline 10. & CPD21 & 7.1337 & -0.7975 & 3.6808 \\
\hline 11. & CPD03 & 6.5258 & -0.7834 & 3.645 \\
\hline 12. & CPD16 & 5.4123 & -0.6506 & 3.0827 \\
\hline 13. & CPD18 & 5.4092 & -0.4971 & 3.0934 \\
\hline 14. & CPD09 & 5.3794 & -2.0629 & 5.5779 \\
\hline 15. & CPD04 & 5.0546 & -0.8747 & 3.314 \\
\hline 16. & CPD17 & 4.9768 & -0.5406 & 2.5312 \\
\hline 17. & CPD06 & 4.8464 & -0.4294 & 2.7807 \\
\hline 18. & CPD12 & 4.7746 & -0.2911 & 3.6919 \\
\hline 19. & CPD02 & 4.3294 & -0.5312 & 3.2295 \\
\hline 20. & CPD23 & 4.2525 & -0.3915 & 2.3399 \\
\hline 21. & CPD05 & 4.2156 & -1.7538 & 2.8872 \\
\hline 22. & CPD10 & 3.9722 & -0.6071 & 1.9545 \\
\hline 23. & CPD11 & 3.8578 & -1.0167 & 3.0595 \\
\hline 24. & CPD01 & 3.8079 & -0.7685 & 3.1815 \\
\hline 25. & CPD08 & 3.6961 & -0.5147 & 3.4152 \\
\hline
\end{tabular}

Crash score: revealing the inappropriate penetration into the binding site

Polar score: reports the polar region of the ligands

The number of hydrogen bonds formed between different residues of protein and ligands during the course of the simulation was also calculated (Fig. 6c). From the observed graph, it is understood that the different complexes formed a different number of hydrogen bonds, with an average value of $\sim 0-3$ number. For comparison, reference ligand formed extra number of hydrogen bond than CPD07 and CPD21. It is interesting to observe that the number of hydrogen bond $(\mathrm{NH})$ formed and maintained during the MD simulation is in very much consistent with the docking results, but the fluctuation in the number of hydrogen bond can only be explained by the dynamic movement of the protein and interacting ligands during the simulation time, which may introduce or omitted few hydrogen bonds over the whole simulation time.

To measure the compactness of the hydrophobic core forming between different protein-ligand complexes, SASA (solvent accessible surface area) were measured (Fig. 6d). Results show diversity in SASA values, observed with different PPAR $\gamma$ complexes, particularly PPARy-CPD07 complex shows higher values of SASA (56-60 $\mathrm{nm}$ ), whereas CPD21 and reference ligand with PPARY complex show lower SASA value $(55-59 \mathrm{~nm})$.

Further, C-RMSF is calculated to observe the overall flexibility of atomic positions in the trajectory for the proteins and their complexes (Fig. 6e. I and e. II). The PPARY protein with CPD07 and CPD21 showed a significant change in protein structure conformation with an increase in the C-RMSF values but interestingly the active site amino acid residues such as, Gln286, Ser289, Ser314, His323, Lue330, Met364 and His449 fluctuated at very narrow range, indicating the protein structure conformation is conserved.

\section{Chemistry and synthesis}

Rationally designed target compounds belonging to the class of 2-(4-((substituted phenylimino)methyl)phenoxy)acetic acid; (CPD01-24) were synthesized according to the Scheme $1[28,29]$. Two aromatic aldehydes, namely, viz. 4-hydroxy benzaldehyde and 4-hydroxy3-methoxy benzaldehyde (vanillin) were selected as building blocks. In the first and second step of total synthesis, we have converted hydroxyl group of aldehyde to corresponding phenoxy-acetic acids by adopting the modified procedure of Williamson ether synthesis [30, 31]. Further, the aldehyde functional group was condensed with primary aromatic amines to form Schiff base via imine linkage [32-35]. From our observational perspective it was found that, phenoxy-acetic acid moiety of intermediates hinders the interaction of aldehyde and amines of different reactants and hence formation of imine linkages also deters. The structures of the synthesized glitazars confirmed via IR, NMR and Mass spectral interpretation, data of respective studies are provided at experimental section.

The appearance of characteristic peak in the range of 1580.50 to $1604.90 \mathrm{~cm}^{-1}$ in all IR spectra along with the absence of $\mathrm{NH}$ stretch proved the formation of imine bond $(\mathrm{CH}=\mathrm{N})$. All the compounds showed characteristic $\mathrm{C}=\mathrm{O}$ stretching of carboxyl group in the range of 


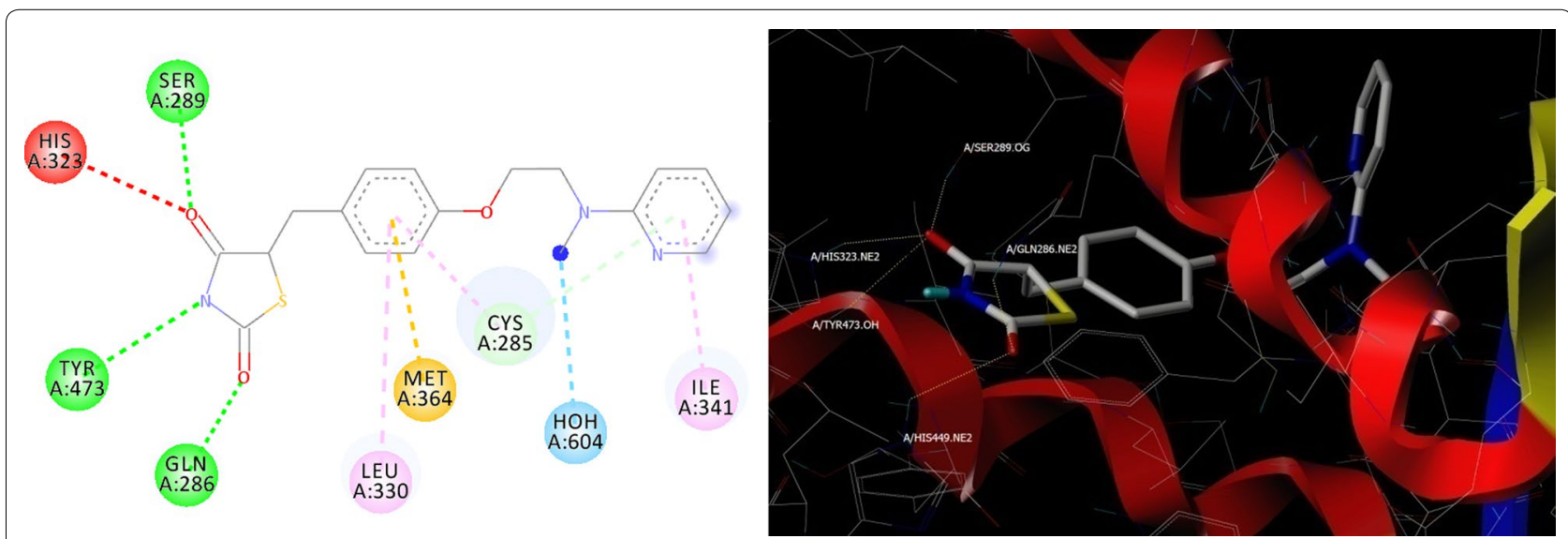

Fig. 4 Binding pose of reference ligand (pioglitazone) present in PPARY (PDB code: 3CS8) before (2D) and after (3D) Docking studies, His 323, His 449, Tyr 473, Ser 289 and GIn 286 are important binding pocket amino acids to form hydrogen bonds (yellow dots)

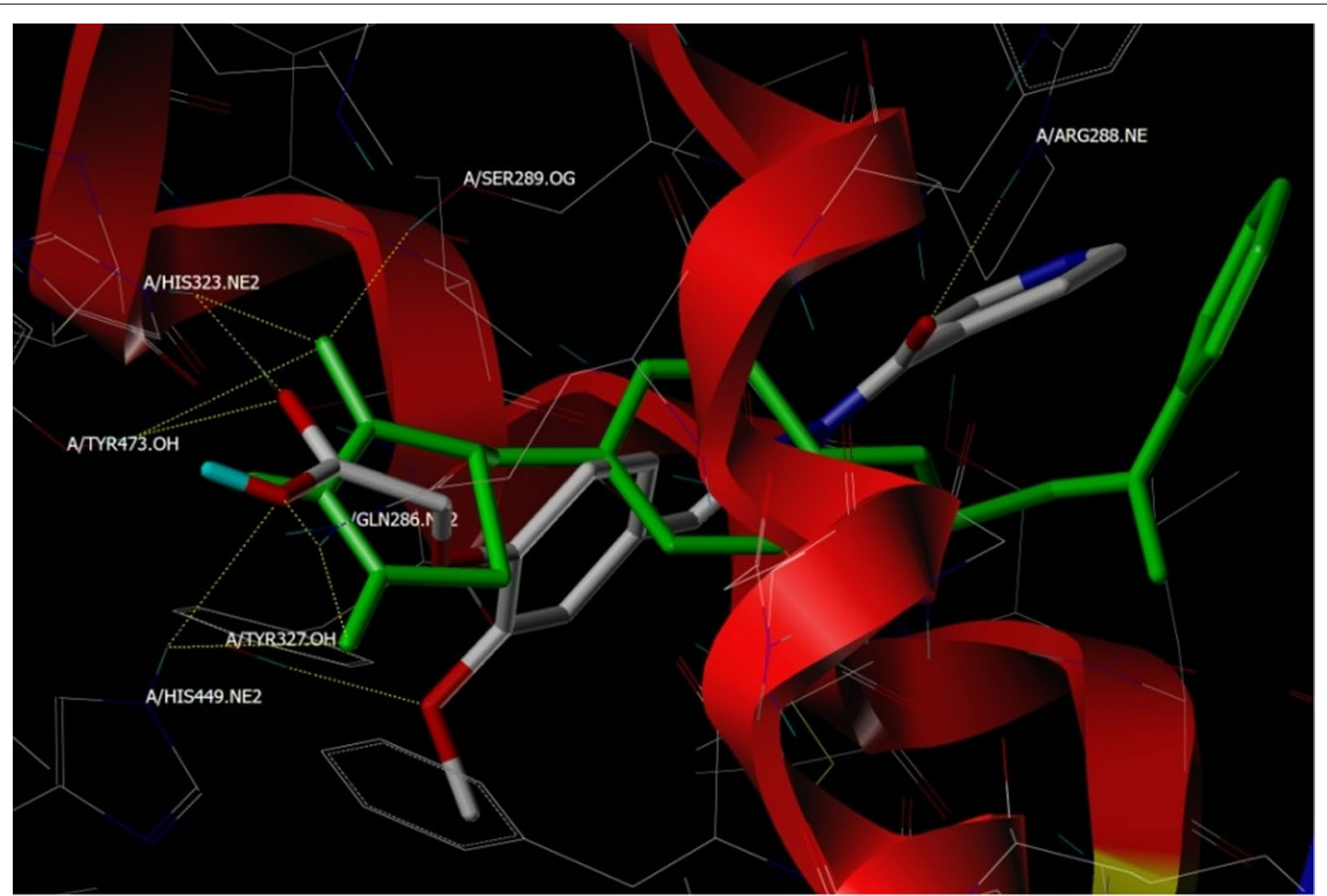

Fig. 5 Overlap of pioglitazone (green color) and CPD20 (atom type color) at the binding site of PPARy showing comparable hydrogen bonding (yellow dots) interactions with amino acids; His 323, Tyr 473, Tyr 327, Gln 286, His 449 and Arg 288 at the binding site

1650.42 to $1743.35 \mathrm{~cm}^{-1}$ along with $\mathrm{O}-\mathrm{H}$ stretching in the range of 3200.25 to $3400.23 \mathrm{~cm}^{-1}$.

From ${ }^{1} \mathrm{H}-\mathrm{NMR}$ spectra it is observed that methylene protons $\left(\mathrm{CH}_{2}\right)$, which are bridge between phenoxy and carboxylic acid moiety appeared as singlet in the range of $\delta 4.45 \mathrm{ppm}$ to $\delta 4.68 \mathrm{ppm}$ and proton attached to imine linkage $(\mathrm{H}-\mathrm{C}=\mathrm{N})$ of Schiff base has resonated between $\delta 8.23 \mathrm{ppm}$ to $\delta 8.98 \mathrm{ppm}$ which intern confirmed the formation of imine. It is very interesting to notice that CPD06, 09, 10, 16, 19 and 20 showed, $-\mathrm{CH}$ signal of imine $(-\mathrm{CH}=\mathrm{N})$ deshielded to the $\delta$ ppm 8.9 and above, which is possible when the configuration at $-\mathrm{CH}=\mathrm{N}$ linkage is ' $\mathrm{E}$ ' form.

The first step of synthesis involves salt formation of the hydroxyl group by stirring with sodium hydroxide in aqueous medium, further, condensation of the phenoxide sodium with equivalent amounts of chloro acetic acid were done in presence of sodium hydroxide. The method 


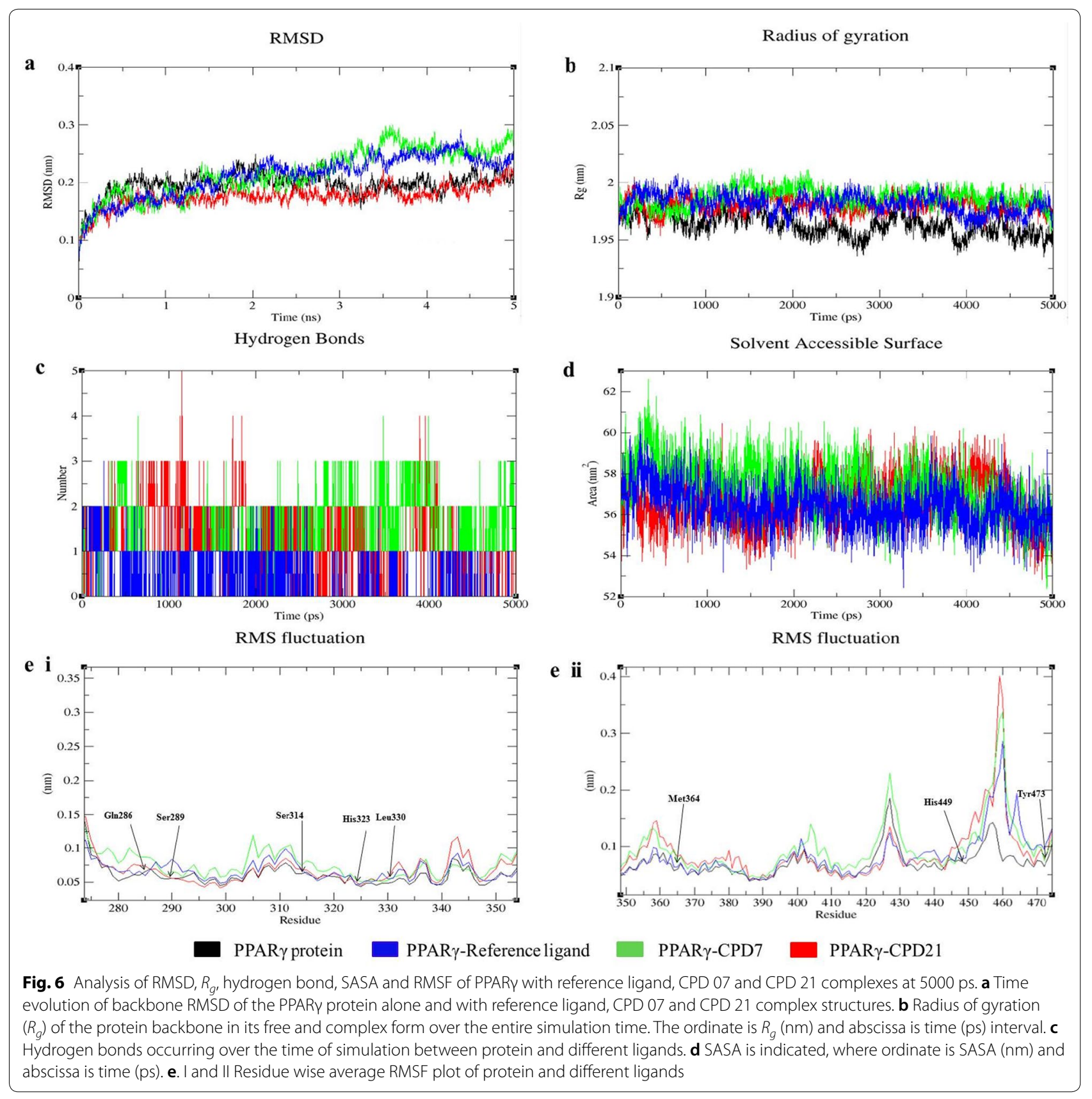

adopted to synthesize the phenoxyacetic acid was very useful as it yields $70-80 \%$ of the product with a little modification to the Williamson ether synthesis. Finally, the formed intermediate was utilized to unite to the lipophilic tail by condensing the aldehydic moiety with different substituted aromatic amines using absolute alcohol as solvent in the presence of catalytic amount of acetic acid and few beads of activated molecular sieves. Final products were purified by column chromatography using ethyl acetate and $n$-hexane as solvent system by gradient elution technique.
Reagents and Condition: (a) $\mathrm{NaOH}, \mathrm{H}_{2} \mathrm{O}$, stir (b) $\mathrm{ClCH}_{2} \mathrm{COOH}, \mathrm{NaOH}, \mathrm{H}_{2} \mathrm{O}$ reflux at $120-140{ }^{\circ} \mathrm{C}$ for $3 \mathrm{~h}$ (c) Substituted aromatic amine, gl. acetic acid, absolute ethanol, molecular sieves, reflux with stirring for 8-12 h.

\section{Biological screening}

To evaluate the biological activity of the synthesized compounds, as a first measure, we screened for cytotoxicity followed by glucose uptake assays. 


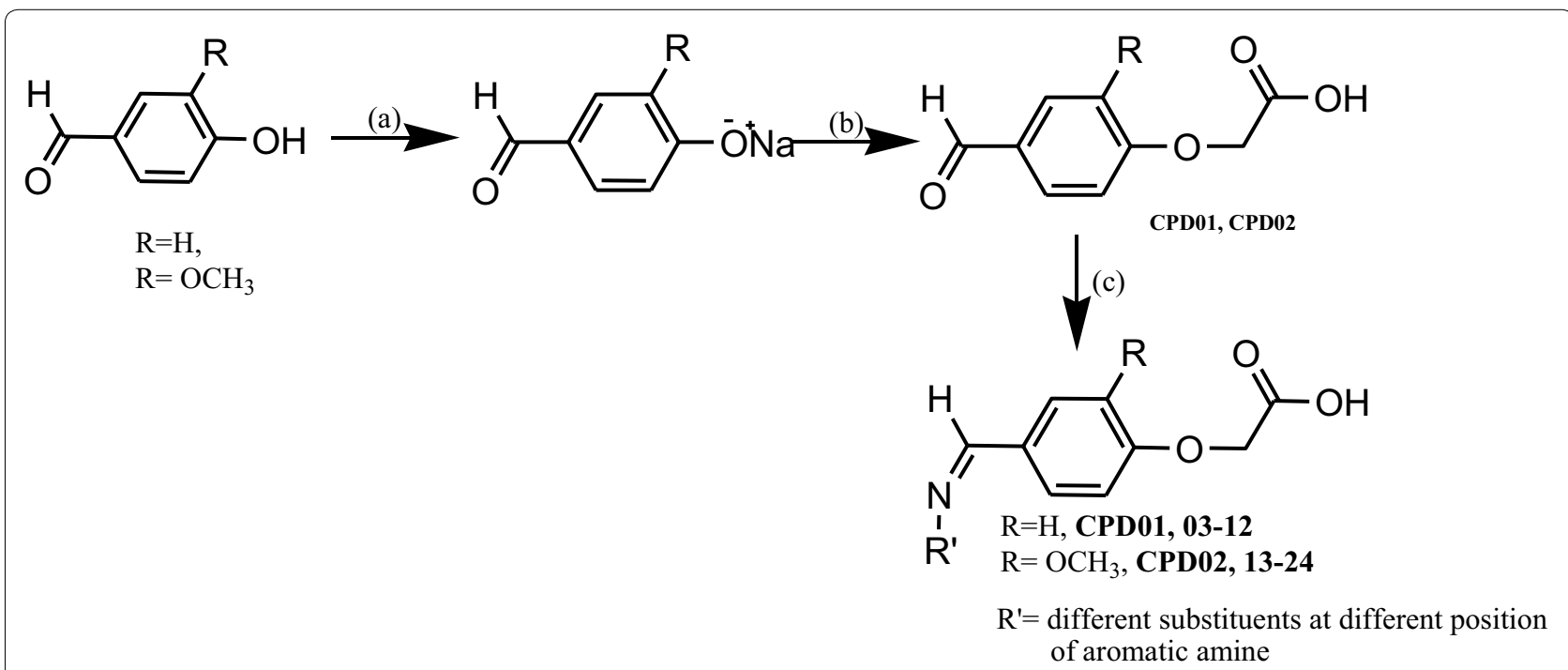

Scheme 1 Synthesis of target phenoxyacetic acid based glitazones CPD01-24

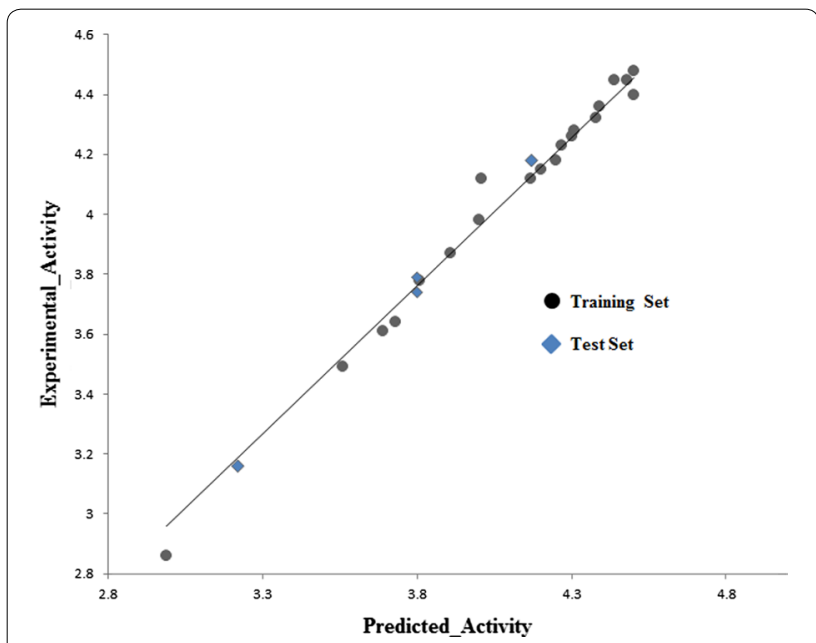

Fig. 7 Plot of experimental vs. predicted activity for CoMSIA model of glucose uptake activity

\section{In vitro cytotoxic assay}

All the designed and synthesized 24 compounds were undergone MTT assay to evaluate the cytotoxic concentration levels [36]. Measurement of cytotoxic concentration is always a prerequisite for any in vitro assay. The assay depends both on the number of cells live and dead. The cleavage of MTT to a blue formazan derivative by live cellsby the influence of test compounds, is clearly a very effective means of measuring cytotoxicity [37]. The principle involved is the cleavage of tetrazolium salt MTT (3-(4,5 dimethyl thiazole-2 yl)-2,5-diphenyl tetrazolium bromide) into a blue coloured product (formazan) by mitochondrial enzyme succinate dehydrogenase.
The results obtained for cytotoxic assay is as shown in Table 4.

Cytotoxicity results revealed the different cytotoxic concentration levels of synthesized compounds which are in the range of 15.87 to $398.59 \mu \mathrm{g} / \mathrm{ml}$ with respect to the standard pioglitazone $\left(\mathrm{CTC}_{50} 17.56 \mu \mathrm{g} / \mathrm{ml}\right)$. Cytotoxicity results reveal that the designed molecules are less toxic to the cells when compared with the standard pioglitazone.

\section{In vitro glucose uptake assay}

The skeletal muscles account for more than $80 \%$ of insulin-stimulated glucose uptake, an impaired glucose uptake in skeletal muscle is responsible for the development of type II diabetes mellitus [38]. The initial ratelimiting step for glucose clearance in skeletal muscle and adipose tissue is the transport of glucose through a family of specific glucose transporters (GLUT) [38] that are either constitutively presents in plasma membrane or actively translocated to the plasma membrane. A skeletal muscle expresses GLUT1 and GLUT4 glucose transporters. GLUT4 is the main glucose carrier expressed in skeletal muscle, whereas GLUT1 accounts for only $5-10 \%$ of total glucose carrier. The regulation of glucose and insulin of the muscle, specific facilitative glucose transport system GLUT4 was investigated in L6 muscle cells in culture $[39,40]$. The percentage of glucose uptake activity or anti-diabetic activity for test samples was calculated which is depicted in Table 5 .

In vitro glucose uptake activity results indicate that CPD03, 07, 08, 12, 19, 20 and 21 has almost identical activity even when compared to standard drug. Other compounds have shown low to moderate glucose uptake 
Table 4 Cytotoxicity data for the synthesized compounds against 3T3-L1 cells

\begin{tabular}{llc}
\hline Sl. no. & Compound & CTC $_{\mathbf{5 0}} \mathbf{\mu g} \mathbf{m} \mathbf{m}$ \\
\hline 1. & CPD01 & 110.78 \\
2. & CPD02 & 44.16 \\
3. & CPD03 & 88.38 \\
4. & CPD04 & 223.59 \\
5. & CPD05 & 126.28 \\
6. & CPD06 & 398.59 \\
7. & CPD07 & 15.87 \\
8. & CPD08 & 114.86 \\
9. & CPD09 & 155.65 \\
10. & CPD10 & 150.86 \\
11. & CPD11 & 102.62 \\
12. & CPD12 & 109.88 \\
13. & CPD13 & 151.86 \\
14. & CPD14 & 121.98 \\
15. & CPD15 & 91.98 \\
16. & CPD16 & 19.95 \\
17. & CPD17 & 101.63 \\
18. & CPD18 & 21.15 \\
19. & CPD19 & 125.19 \\
20. & CPD20 & 128.36 \\
21. & CPD21 & 101.37 \\
22. & CPD22 & 68.92 \\
23. & CPD23 & 61.71 \\
24. & CPD24 & 43.41 \\
25. & Pioglitazone \\
\hline & & 17.56 \\
\hline
\end{tabular}

activity. Most of the compounds having Vanillin moiety as their trunk showed good activity when compared to others. This could possibly because of additional methoxy group attached to the aromatic ring and supposedly same observations were noted from docking results as well; indicating some apparent correlation between the structures, docking results and the glucose uptake activity.

\section{D QSAR (CoMSIA) studies}

Considering the structural diversity of synthesized glitazones and their glucose uptake activity through PPAR agonistic property; we subjected the group for 3D QSAR studies.

Computational method like Comparative Molecular Similarity Indices Analysis (CoMSIA) [41] was adopted to study the 3D QSAR. This methodology enables us to understand the structural features in 3D space that required to show the activity and also to bind to target receptors. Another advantage of performing CoMSIA
Table 5 Glucose uptake activity of the synthesized compounds

\begin{tabular}{|c|c|c|}
\hline Sl. no. & Compound & $\begin{array}{l}\text { \% glucose } \\
\text { uptake } \\
\text { overcontrol }\end{array}$ \\
\hline 1. & Standard 1 & 89 \\
\hline 2. & Standard 2 & 94 \\
\hline 3. & CPD01 & 45 \\
\hline 4. & CPD02 & 50 \\
\hline 5. & CPD03 & 81 \\
\hline 6. & CPD04 & 74 \\
\hline 7. & CPD05 & 67 \\
\hline 8. & CPD06 & 45 \\
\hline 9. & CPD07 & 89 \\
\hline 10. & CPD08 & 90 \\
\hline 11. & CPD09 & 20 \\
\hline 12. & CPD10 & 42 \\
\hline 13. & CPD11 & 75 \\
\hline 14. & CPD12 & 72 \\
\hline 15. & CPD13 & 25 \\
\hline 16. & CPD14 & 70 \\
\hline 17. & CPD15 & 45 \\
\hline 18. & CPD16 & 55 \\
\hline 19. & CPD17 & 35 \\
\hline 20. & CPD18 & 65 \\
\hline 21. & CPD19 & 90 \\
\hline 22. & CPD2O & 80 \\
\hline 23. & CPD21 & 85 \\
\hline 24. & CPD22 & 55 \\
\hline 25. & CPD23 & 40 \\
\hline 26. & CPD24 & 70 \\
\hline
\end{tabular}

study is for contour maps which highlights the structural features and give indication for optimizable areas of the given set of structures to design better active novel molecules [42].

The $\%$ glucose uptake values were transferred to their natural logarithms and used for building the model and analysis. The protocol used here are according to the default settings and standard protocol, unless otherwise noted. The cross-validated correlation coefficient $\left(\mathrm{q}^{2}\right)$ value, number of components, non-cross-validated correlation coefficient $\left(\mathrm{r}^{2}\right)$, standard error of estimation (SEE), Fischer's covariance ratio (F) and contribution of each field components for the developed CoMSIA model areas shown in Table 6. The statistical parameters of the model indicated good predictive ability of developed model.

The validation and robustness of the developed model was assured by the good $\mathrm{q}^{2}$ values $\left(\mathrm{q}^{2}>0.5\right)$ [43], 
Table 6 Statistical parameters of developed CoMSIA model for glucose uptakeactivity

\begin{tabular}{ll}
\hline Statistics & $\begin{array}{l}\text { Glucose } \\
\text { uptake } \\
\text { activity }\end{array}$ \\
\hline Grid spacing $(\AA)$ & 2.0 \\
$\mathrm{q}^{2}(\mathrm{LOO})$ & 0.712 \\
$\mathrm{r}^{2}$ & 0.889 \\
$\mathrm{~S}$ & 0.211 \\
$\mathrm{~F}$ & 121 \\
No. of components & 6 \\
Contribution of- & \\
Steric & 0.080 \\
Electrostatic & 0.062 \\
Hydrophobic & 0.322 \\
Hydrogen bond donor & 0.234 \\
Hydrogen bond acceptor & 0.302 \\
\hline
\end{tabular}

$\mathrm{q}^{2}$ : cross-validated correlation coefficient

$r^{2}$ : non-cross-validated correlation coefficient

S: standard error of estimation; F: Fischer's covariance ratio

hence an external set is used to validate the predictivity of the developed model, whereas the correlation0 graph (Fig. 7) of predicted activity vs actual activity of training and test set signifies the good regression.

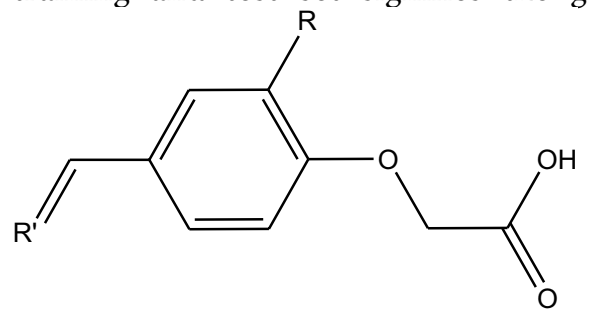

$\mathrm{R}=-\mathrm{H}$ for CPD01, 03-12

$\mathrm{R}=-\mathrm{OCH}_{3}$ for $\mathrm{CPD}$ 02, 13-24
All the molecules were analysed for conformation and aligned by field fit method against the common substructure of all the molecules of training set (Fig. 8).

For CoMSIA, the use of molecular similarity indices avoids the arbitrary definitions of cut off values, and the descriptors can be calculated in all grid points [43]. Developed CoMSIA model provided better-defined contour maps and are as shown in Figs. 9, 10, 11.

\section{Structure-activity relationship for Glucose uptake activity}

The structure-activity relationships based on the above CoMSIA contour maps are as follows; the basic moiety of phenoxyacetic acid with Schiff base linkage is important for possessing the activity as it is the common substructure in all the glitazones. The acidic phenoxyacetic acid, the aromatic ring and lipophillic imine linkage to the aromatic tail, all constitute the pharmacophoric features of the reported glitazones. The image depicted in Fig. 9 is combined contour of steric and electrostatic features for glucose uptake activity, where green and yellow contour area represents steric bulk favoured and disfavoured zone, respectively. Green contour map near to meta position of lipophilic aromatic ring indicates that steric bulk is favoured in that area and the same is observed in CPD14, 15, 19 and 20. Yellow contour near methoxy group near to para position of aromatic ring indicates disfavoured zone for steric bulk and the same is observed in CPD06, 09, 10 and 17. Blue electrostatic contour indicates the favourable zone for electronegative groups and it appear near the methoxyl group in aromatic ring as evidence to it CPD14, 19, 20, 21 and $\mathbf{2 4}$ had similar substitution. In contrast, red contour from meta to para position of terminal aromatic ring indicates disfavoured zone for electronegative atoms and it was observed in CPD10, 15, 17 and 23 (Tables 7 and 8).

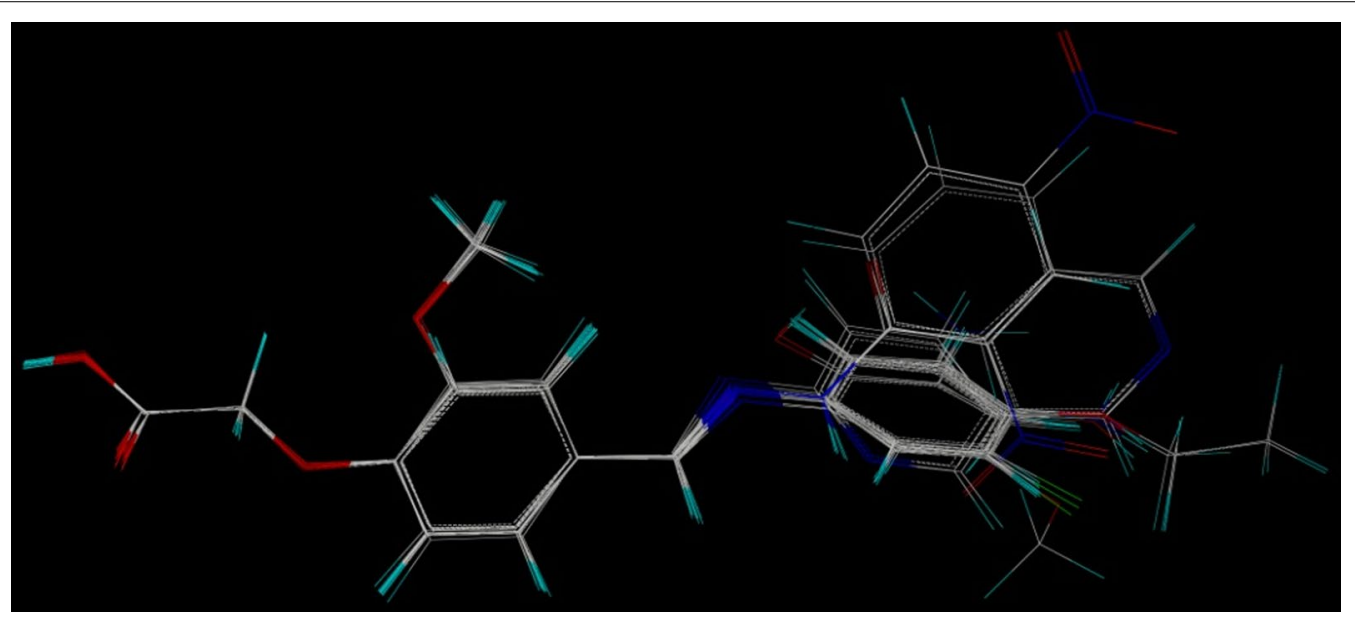

Fig. 8 Training set molecules after alignment by field fit method 


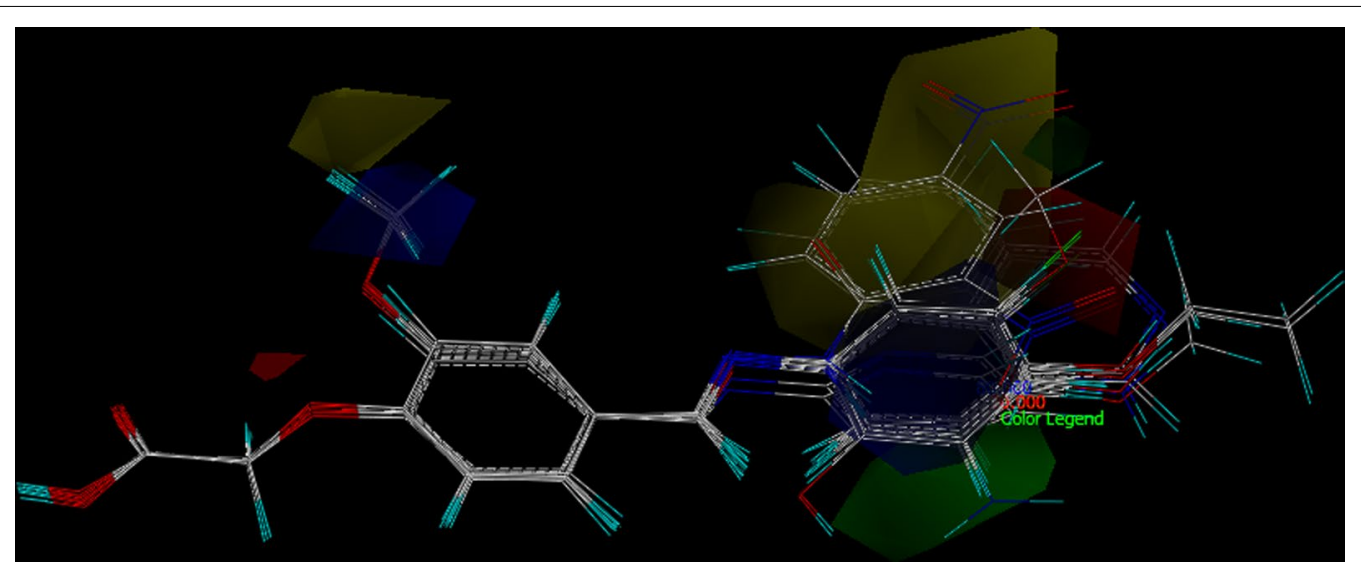

Fig. 9 CoMSIA steric and electrostatic SD x coefficient contour plot; green contours indicate regions where steric bulk is favorable and yellow contours indicate regions where steric bulk is disfavored. Whereas Blue contours indicate regions where electronegative groups increase activity and red contours indicate regions where electropositive groups increase activity

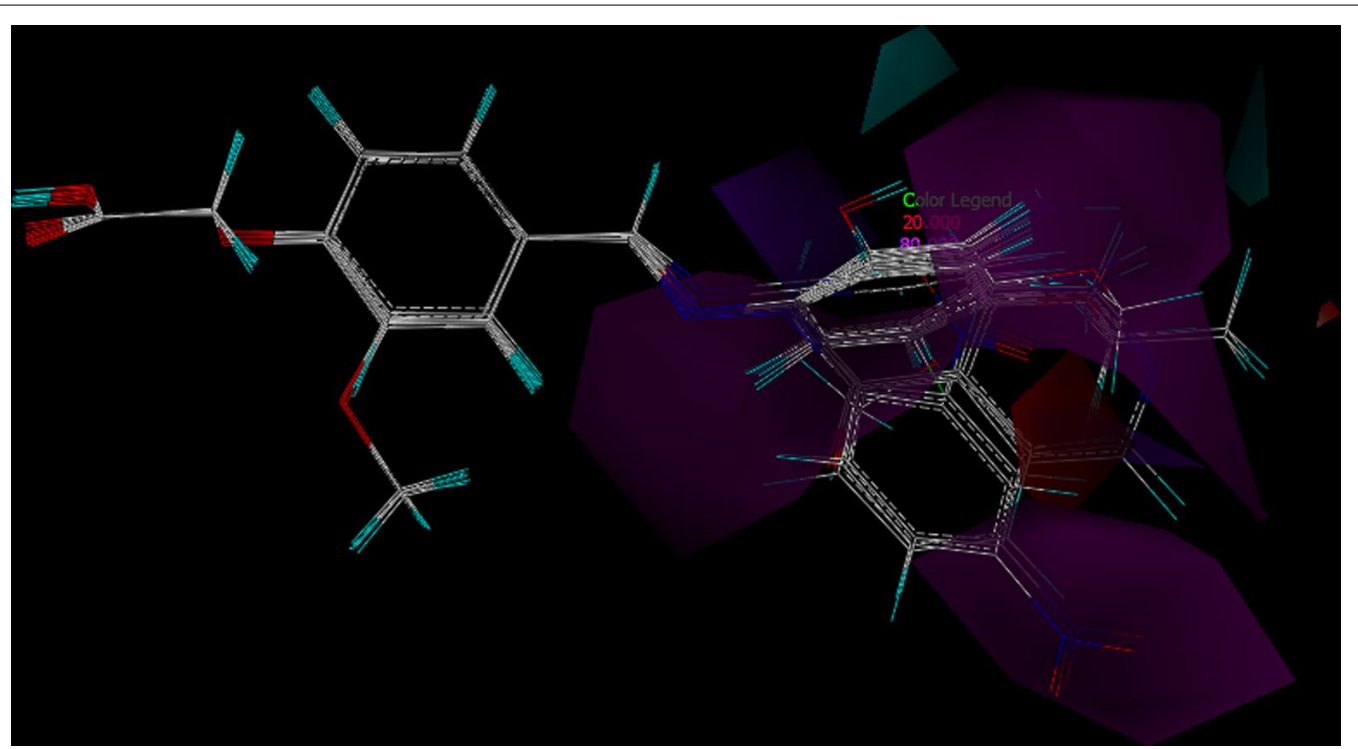

Fig. 10 CoMSIA hydrogen bond donor and hydrogen bond acceptor SD $\times$ coefficient contour plot; cyan contours indicate regions where hydrogen bond donor increase activity and violet contours indicate regions where hydrogen bond donor decrease activity, whereas magenta contours indicate regions where hydrogen bond acceptors increase activity and red contours indicate regions where hydrogen bond donors decrease activity

The combined contour of hydrogen bond donor and acceptor is shown in Fig. 10 where cyan and violet represent hydrogen bond donor favored and disfavored zones, whereas magenta and red represent hydrogen bond acceptor favored and disfavored zones, respectively.

Contour map for hydrophobicity is as depicted in Fig. 11. Where yellow and white colors are representing hydrophobicity favor and disfavor zones, respectively. Yellow region near methoxy of trunk aromatic group and some portion of tail aromatic group favors hydrophobicity, whereas white contour near para of tail aromatic group disfavors hydrophobicity.

\section{Experimental}

Pharmacophore modelling and database screening

Structure based pharmacophore protocol was adopted starting from the PPAR $\gamma$ protein-ligand complex and UNITY search was performed. For building the QUERY and running the UNITY search, we used the SYBYL X 2.1.1 software package (Tripose USA); the overall procedure includes pharmacophoric query generation and 


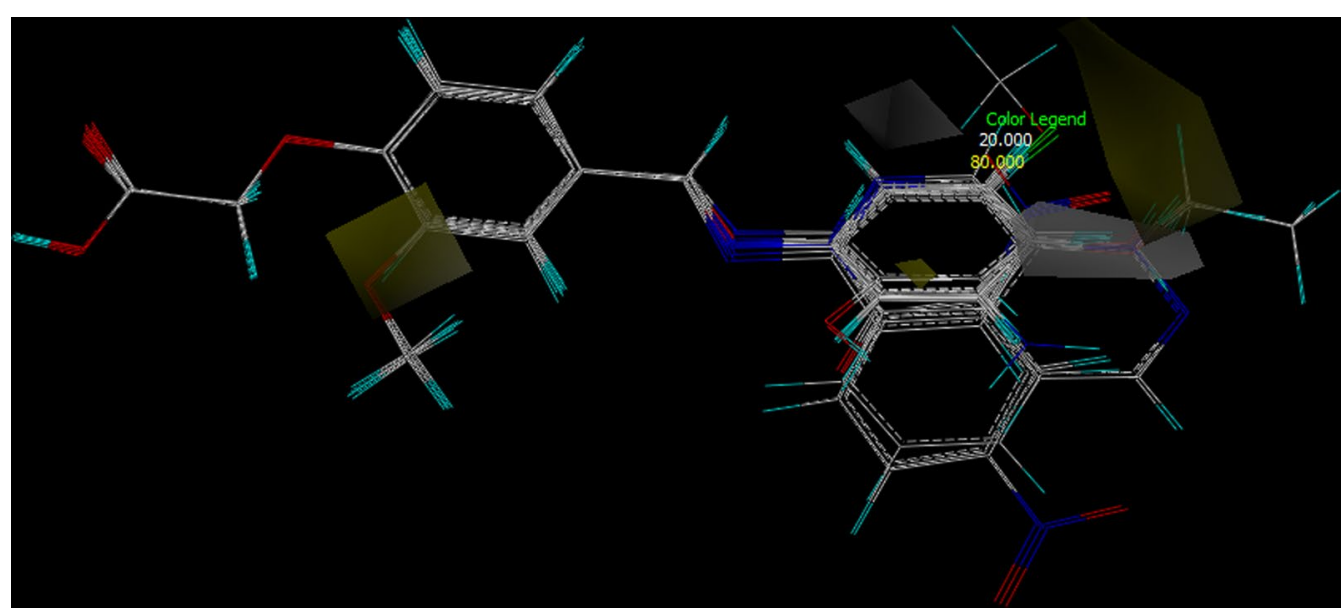

Fig. 11 CoMSIA hydrophobic SD x coefficient contour plot; yellow contours indicate regions where hydrophobicity favors and white contours indicate regions where hydrophobicity disfavours

unity database search. To start the pharmacophore based virtual screening, we build the query by considering the conformation of Pioglitazone complexed with PPAR $\gamma$ (3CS8) protein, by taking the characteristic features of bound ligand (Pioglitazone) in complex with macromolecule (PPAR $\gamma$ ). The special characters included to build the QUERY were, Hydrogen bond donor, Hydrogen bond acceptor, Hydrophobic and Aromatic feature from both ligand and macromolecule, with appropriate tolerance value. The program UNITY SEARCH performs the search algorithm for database of molecules against build query of pharmacophoric features, where the database of active molecules was searched against the build QUERY.

\section{Docking studies}

The designed compounds were virtually sketched and the Docking operation was performed by using SERFLEXDOCK program as a part of the SYBYL-X 2.1.1 software package (Tripose USA) and necessary calculations were done then after. The overall procedure of DOCKING program includes ligand preparation, protein preparation, protomol generation and docking of ligands.

Adaptation of Docking protocol and validation of the same were performed by comparing the binding poses of co-crystalized ligand with amino acids of target proteins PPARy (pdb: 3CS8) before and after the docking study. All the designed and synthesized compounds along with pioglitazone were sketched in the molecular area provided with SYBYL-X 2.1.1 software package, prepared and stored, using ligand preparation wizard, where they were converted to their 3D form, energy minimized and charges were added. The force field used for energy minimization was MMFF94s [44] and charges added to each molecule using Gasteiger-Huckel method [45, 46]. The proteins from Protein Data Bank were prepared by adding Hydrogens and missing amino acids, deleting water molecules and finally applying charges. The energy minimization step was performed using MMFF94s as Force Field and applied Gasteiger-Marsili charges [47] with 1000 iterations of conjugate gradient method in convergence criterion of $1.0 \mathrm{kcal} / \mathrm{mol}$. All these steps were performed on SYBYL-X 2.1.1 software platform using Biopolymer Preparation wizard. The active site of any target protein was identified by the Protomol generation step. In other words, Protomol is the ensemble of different amino acids of any target protein where the desired ligands will bind by different intermolecular interactions with the amino acids. In the present work we had generated the protomol by considering the binding mode of co-crystallized ligand inside the protein cavity. Finally, the prepared ligand and protein were interacted by GEOM mode, where 20 conformers of each ligand were generated, the stable conformer interacting with protein was identified and respective docking scores were then obtained as Total Score, Crash Score and Polar Score.

\section{Molecular dynamics simulation studies}

Molecular Dynamics (MD) simulations were performed for the native protein (PPAR $\gamma$ ) and their docked complexes of PPAR $\gamma$-ligand using GROMACS version 4.5.5 [48] implemented with CHARMM 27 forcefield [49]. The topology file for all the ligands were generated by SwissParam using CHARMM all atoms forcefield [50]. The Van der Waal interactions were calculated with a distance cut-off of $1.0 \mathrm{~nm}$. Partial Mesh Ewald (PME) summation was applied for long range electrostatics with $1 \mathrm{~nm}$ cut-off for columbic interaction [51]. Counter ions were included for the requirement of electro-neutrality condition of the system. The system was solvated using 
Table 7 Compounds considered for the training set

\begin{tabular}{|c|c|c|c|c|}
\hline \multirow[t]{2}{*}{ Compound } & \multirow[t]{2}{*}{$\mathbf{R}^{\prime}$} & \multicolumn{3}{|c|}{ Glucose uptake activity } \\
\hline & & $\operatorname{lnGU}$ & Predicted activity & Residual activity \\
\hline CPD02 & $\mathrm{O}$ & 3.91 & 3.87 & 0.04 \\
\hline CPD03 & & 4.39 & 4.36 & 0.03 \\
\hline CPD04 & & 4.30 & 4.26 & 0.04 \\
\hline CPD05 & & 4.20 & 4.15 & 0.05 \\
\hline CPD07 & & 4.48 & 4.45 & 0.03 \\
\hline CPD08 & & 4.50 & 4.40 & 0.10 \\
\hline CPD09 & & 2.99 & 2.86 & 0.13 \\
\hline CPD10 & & 3.73 & 3.64 & 0.09 \\
\hline CPD11 & & 4.31 & 4.28 & 0.03 \\
\hline CPD12 & & 4.27 & 4.23 & 0.04 \\
\hline CPD14 & & 4.25 & 4.18 & 0.07 \\
\hline CPD15 & & 3.81 & 3.78 & 0.03 \\
\hline CPD16 & & 4.00 & 3.98 & 0.02 \\
\hline
\end{tabular}


Table 7 (continued)

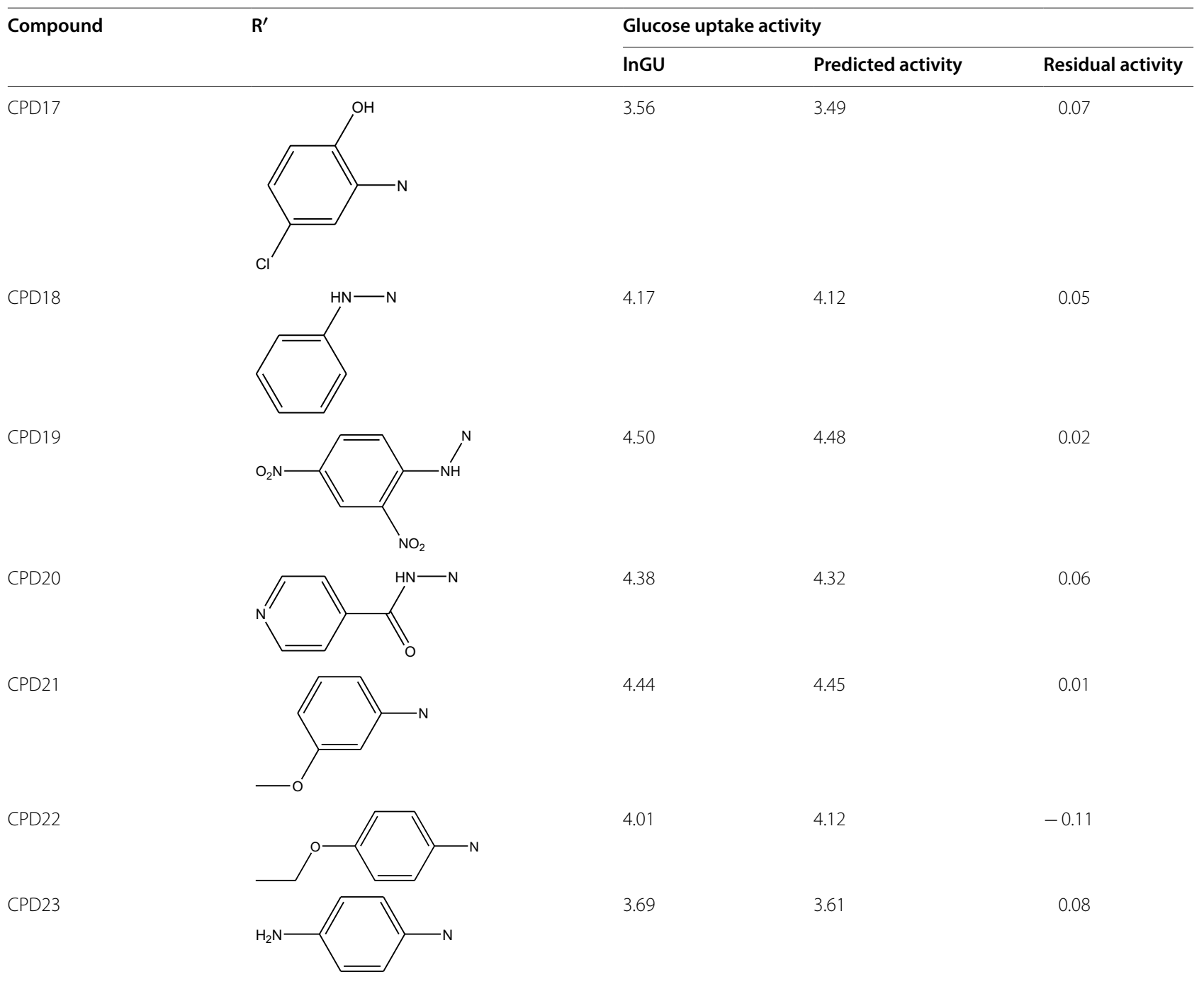

TIP3P water model $[52,53]$ and simulated in a triclinic box with protein atoms apart to $1.5 \mathrm{~nm}$ from the wall of the box dimensions along with periodic boundary conditions. The structures were first energy minimized using steepest descent algorithm with a tolerance of $1000 \mathrm{KJ} /$ $\mathrm{mol} / \mathrm{nm}$. The system was equilibrated by applying position restrains on the complex and performing simulations using canonical NVT ensembles followed by NPT. Both the equilibration was run for 200 ps each at a temperature of $300 \mathrm{~K}$ and 1 bar. Temperature coupling was performed using velocity rescaling [54] with a coupling constant of $0.1 \mathrm{ps}$ and the initial velocities were generated according to Maxwell distribution. Temperature-pressure coupling was performed using extended ensemble Parrinello-Rahman algorithm [55] with a coupling constant of 2 ps. The equilibrated system was then subjected to $5 \mathrm{~ns}$ of production run. A time step integration of $2 \mathrm{fs}$ was used. The trajectories were saved every 500 steps and analyzed using GROMACS analysis tools and XMGRACE-5.1.22 program (http://plasma-gate.weizm ann.ac.il/Grace/).

\section{Chemistry}

All the synthetic work was done by procuring available laboratory grade reagents and analytical grade solvents. The solvents and reagents were used as such provided by the manufacturer. TLC was performed to monitor the reactions and to determine the purity of the products. All the reported compounds were purified by column chromatography. The melting points of the synthesized compounds were determined in open capillary method, expressed in ${ }^{\circ} \mathrm{C}$. IR spectra of compounds were recorded on Shimadzu FT-IR 8400-S spectrophotometer by $\mathrm{KBr}$ 
Table 8 Compounds of the test set

\begin{tabular}{|c|c|c|c|c|}
\hline \multirow[t]{2}{*}{ Compound } & \multirow[t]{2}{*}{$\mathbf{R}^{\prime}$} & \multicolumn{3}{|c|}{ Glucose uptake activity } \\
\hline & & $\operatorname{lnGU}$ & $\begin{array}{l}\text { Predicted } \\
\text { activity }\end{array}$ & Residual activity \\
\hline CPD01 & $\mathrm{O}$ & 3.80 & 3.74 & 0.06 \\
\hline CPD06 & & 3.80 & 3.79 & 0.01 \\
\hline CPD13 & & 3.22 & 3.16 & 0.06 \\
\hline CPD24 & & 4.17 & 4.18 & -0.01 \\
\hline
\end{tabular}

pellet technique and are expressed in $\mathrm{cm}^{-1} \cdot{ }^{1} \mathrm{H}-\mathrm{NMR}$ and ${ }^{13} \mathrm{C}$-NMR spectra were recorded on Bruker $400 \mathrm{MHz}$ FTNMR spectrophotometer using DMSO $\mathrm{D}_{6}$ and $\mathrm{CDCl}_{3}$ as the solvents and TMS as internal standard ( $\delta \mathrm{ppm})$. Mass spectra were obtained using LC-MS ACQUITY UPLC mass spectrometer under ES ionization at $70 \mathrm{eV}$ and Time of flight detector. Retention Time (RT) also observed on the same UPLC instrument by maintaining the below mentioned optimized chromatographic condition: Column: $\mathrm{C}_{18} 1.7$ micron, Flow rate: $0.4 \mathrm{ml} / \mathrm{min}$, Run time: $15 \mathrm{~min}$, Injection volume: $10 \mu \mathrm{l}$, Detector: PDA Detector, TOF, Elution: Gradient, Mobile phase: $0.1 \%$ FA in water and Acetonitrile, Column temperature: $60^{\circ} \mathrm{C}$.

\section{General procedure for the synthesis of sodium phenoxide}

Sodium phenoxide from the vanillin and $p$-hydroxybenzaldehyde was prepared by taking $0.02 \mathrm{M}$ equivalents of vanillin or $p$-hydroxybenzaldehyde in a beaker, added $0.02 \mathrm{M}$ Sodium hydroxide and $20 \mathrm{ml}$ of distilled water and the solution was mechanically stirred at room temperature, until whole solution became clear [56].

\section{General procedure for the synthesis of formylphenoxyacetic acid}

Formylphenoxyacetic acid was prepared by modifying Williamsons ether synthesis protocol [28], by taking sodium phenoxide and treating it with equivalent amounts of chloroacetic acid in presence of sodium hydroxide. The whole solution of prepared sodium phenoxide in the previous step was taken in a beaker, to that $30 \mathrm{ml}$ of chloroform was added and the solution was stirred mechanically for a period of $10 \mathrm{~min}$ at room temperature. To the above solution $0.02 \mathrm{M}$ chloroacetic acid crystals dissolved in $15 \mathrm{ml}$ of distilled water and another $0.02 \mathrm{M}$ sodium hydroxide pellets dissolved in $15 \mathrm{ml}$ of distilled water were also added. The whole solution was continued to stir for another $10 \mathrm{~min}$. The resultant mixture was allowed to settle, then the whole mixture was poured into a separating funnel and the aqueous layer was taken in a round bottom flask, and the solution was refluxed with stirring at a temperature of $120-140{ }^{\circ} \mathrm{C}$ for $3 \mathrm{~h}$. Reaction mixture was allowed to cool at room temperature and concentrated $\mathrm{HCl}$ was added drop wise until the precipitation stops, filtered and added $20 \mathrm{ml}$ of chloroform and suspended in separating funnel. To this mixture saturated solution of sodium bicarbonate was added until whole precipitate goes into the aqueous phase. The aqueous phase thus separated was added concentrated $\mathrm{HCl}$ slowly, precipitate starts reappearing, filtered and dried.

2-(4-formylphenoxy)acetic acid (CPD01). Pale brown solid, yield $75 \%$, mp $185-187^{\circ} \mathrm{C}$; IR $\left(\mathrm{KBr}, \mathrm{cm}^{-1}\right)$ : 3448.84 (O-H, Acid), 3069.00 (ArC-H), 1759.14 (C=O, Acid), 1651.12 (C=O, Aldehyde), $1427.37 \quad(\mathrm{C}-\mathrm{C}), 1226.77$ $(\mathrm{C}-\mathrm{O}) ;{ }^{1} \mathrm{H}$ NMR $\left(\delta \mathrm{ppm}, \mathrm{CDCl}_{3}\right): 4.487\left(\mathrm{~s}, 2 \mathrm{H}, \mathrm{CH}_{2}\right)$, 6.837-7.655 (m, 4H, ArH), 9.694 (s, $1 \mathrm{H}, \mathrm{CHO}) ;{ }^{13} \mathrm{C}$ NMR: $\left(\delta \mathrm{ppm}, \mathrm{CDCl}_{3}\right)$ : 55.734, 114.826, 114.956, 129.924, 132.351, 158.067, 163.321, 185.231; MS (m/z): $\mathrm{M}+1$ peak found 181.0835, $(\mathrm{M}+1$ peak calculated 181.16). Mass fragments (m/z): 181.0835, 182.0845; HPLC (RT): 3.19 min.

2-(4-formyl-2-methoxyphenoxy)acetic acid (CPD02). Off white solid, yield $60 \%$, mp $145-147{ }^{\circ} \mathrm{C}$; IR $(\mathrm{KBr}$, $\left.\mathrm{cm}^{-1}\right)$ : $3510.56(\mathrm{O}-\mathrm{H}$, Acid), $3091.99(\mathrm{ArC}-\mathrm{H}), 1766.85$ ( $\mathrm{C}=\mathrm{O}$, Acid), $1643.41(\mathrm{C}=\mathrm{O}$, Aldehyde), $1411.94(\mathrm{C}-\mathrm{C})$, $1273.06(\mathrm{C}-\mathrm{O}) ;{ }^{1} \mathrm{H}$ NMR $\left(\delta \mathrm{ppm}, \mathrm{CDCl}_{3}\right): 3.849(\mathrm{~s}, 3 \mathrm{H}$, $\left.\mathrm{OCH}_{3}\right), 4.656\left(\mathrm{~s}, 2 \mathrm{H}, \mathrm{CH}_{2}\right), 6.814-7.347(\mathrm{~m}, 3 \mathrm{H}, \mathrm{ArH})$, $9.758(\mathrm{~s}, 1 \mathrm{H}, \mathrm{CHO}) ;{ }^{13} \mathrm{C}$ NMR: $\left(\delta \mathrm{ppm}, \mathrm{CDCl}_{3}\right): 52.315$, $54.125, \quad 55.734,108.950,109.521,124.021,130.328$, 150.356, 153.745, 163.351, 185.213; MS (m/z): M+1 peak found 211.0897, ( $\mathrm{M}+1$ peak calculated 211.05). Mass fragments (m/z): 211.0897, 212.0941; HPLC (RT): $3.33 \mathrm{~min}$.

\section{General procedure for the synthesis of Schiff base}

The imine $(-\mathrm{CH}=\mathrm{N}-)$ linkage between an amine and aldehyde was made by taking equivalent quantity of amine and aldehyde with catalytic amount of glacial acetic acid, stirred with or without heating according to the procedure reported by Hugo Schiff (1864) [29]. In the present study, we have synthesized the Schiff base by taking equimolar quantities of formylphenoxyacetic acid and substituted aromatic amine. Both of them were dissolved in absolute ethanol and mixed together, to that few drops of glacial acetic acid and few activated molecular sieves were added and finally stirred and refluxed at $80-90{ }^{\circ} \mathrm{C}$ 
for 8-12 h. The reaction was monitored from time to time by drawing samples and checked TLC. The formed precipitate was filtered washed with minimal quantities of cold aqueous ethanol and purified by column chromatography using $25 \%$ ethyl acetate in pet ether as mobile phase and silica gel as stationary phase.

2-(4-((E)-(phenylimino)methyl)phenoxy)acetic acid (CPD03). Yellow amorphous solid, yield 73\%, mp 193$195{ }^{\circ} \mathrm{C}$; IR (KBr, cm ${ }^{-1}$ ): 3263.66 (O-H, Acid), 3016.77 (Ar-H), 1743.71 ( $\mathrm{C}=\mathrm{O}$, Acid), $1604.83(\mathrm{C}=\mathrm{N}$, Imine), $1427.37(\mathrm{C}-\mathrm{N}), 1273.06(\mathrm{C}-\mathrm{O}){ }^{1}{ }^{1} \mathrm{H} \mathrm{NMR}\left(\delta \mathrm{ppm}, \mathrm{CDCl}_{3}\right)$ : $4.574\left(\mathrm{~s}, 2 \mathrm{H}, \mathrm{CH}_{2}\right), 6.548-7.478(\mathrm{~m}, 9 \mathrm{H}, \mathrm{ArH}), 8.255$ (s, $1 \mathrm{H}, \mathrm{CH}=\mathrm{N}) ;{ }^{13} \mathrm{C}$ NMR: $\left(\delta \mathrm{ppm}, \mathrm{CDCl}_{3}\right): 65.054,114.410$, $114.410,122.312,122.312,126.124,127.321,130.121$, $130.321,130.245,130.245,153.278,160.145,163.004$, 173.258; MS $(\mathrm{m} / \mathrm{z}): M+1$ peak found 256.1238, $(M+1$ peak calculated 256.09). Mass fragments (m/z): 256.1238, 257.1389; HPLC (RT): 4.15 min.

2-(4-((E)-(4-methoxyphenylimino)methyl)phenoxy) acetic acid (CPD04). Pale yellow amorphous solid, yield 68\%, mp 189-192 ${ }^{\circ} \mathrm{C}$; IR ( $\left.\mathrm{KBr}, \mathrm{cm}^{-1}\right)$ : $3425.69(\mathrm{O}-\mathrm{H}$, Acid), 3070.78 (Ar-H), 1766.85 (C=O, Acid), 1604.83 ( $\mathrm{C}=\mathrm{N}$, Imine), $1288.49(\mathrm{C}-\mathrm{N}), 1249.91(\mathrm{C}-\mathrm{O}) ;{ }^{1} \mathrm{H}$ NMR $\left(\delta \mathrm{ppm}, \mathrm{DMSO} \mathrm{D}_{6}\right): 3.737\left(\mathrm{~s}, 3 \mathrm{H}, \mathrm{OCH}_{3}\right), 4.653(\mathrm{~s}, 2 \mathrm{H}$, $\left.\mathrm{CH}_{2}\right), 6.915-7.811(\mathrm{~m}, 8 \mathrm{H}, \mathrm{ArH}), 8.510(\mathrm{~s}, 1 \mathrm{H}, \mathrm{CH}=\mathrm{N})$; ${ }^{13} \mathrm{C}$ NMR: $(\delta$ ppm, DMSO D $): 52.296,55.734,65.106$, $114.826,114.955,115.183,115.236,122.620,122.643$, $129.958,130.338,130.429,130.482,144.870,144.931$, 157.983, 158.044, 158.067, 158.112, 160.305, 160.715, 169.381; MS (m/z): $\mathrm{M}+1$ peak found 286.2908, $(\mathrm{M}+1$ peak calculated 286.10). Mass fragments (m/z); 285.2146, 286.2908, 287.0124; HPLC (RT): 2.17 min.

2-(4-((E)-N-(4-hydroxyphenyl)carboximidoyl)phenoxy) acetic acid (CPD05). Yellowamorphous solid, yield 69\%. mp 195-197 ${ }^{\circ} \mathrm{C}$; IR (KBr, cm $\left.{ }^{-1}\right)$ : 3549.14 (O-H, Phenol), 3394.83 (O-H, Acid), 3070.78 (Ar-H), 1694.45 (C=O, Acid), $1604.83(\mathrm{C}=\mathrm{N}$, Imine), $1342.50(\mathrm{C}-\mathrm{N}), 1273.06$ $(\mathrm{C}-\mathrm{O}) ;{ }^{1} \mathrm{H}$ NMR $(\delta$ ppm, DMSO D $): 4.432\left(\mathrm{~s}, 2 \mathrm{H}, \mathrm{CH}_{2}\right)$, 6.620-7.607 (m, 8H, ArH), 8.187 (s, $1 \mathrm{H}, \mathrm{CH}=\mathrm{N}) ;{ }^{13} \mathrm{C}$ NMR: ( $\delta$ ppm, DMSO D $): 65.045,77.172,77.490,77.695$, $77.817,114.743,114.933,115.912,116.018,116.473$, $122.005,129.973,131.795,160.657,190.569 ; \mathrm{MS}(\mathrm{m} / \mathrm{z})$ : $\mathrm{M}+1$ peak found $272.1455,(\mathrm{M}+1$ peak calculated 272.08). Mass fragments $(\mathrm{m} / \mathrm{z}): 272.1455,266.9080$, 259.1119; HPLC (RT): 3.14 min.

2-(4-((E)-(pyridin-2-ylimino)methyl)phenoxy)acetic acid (CPD06). Pale brown amorphous solid, yield 71\%, mp 188-190 ${ }^{\circ} \mathrm{C}$; IR (KBr, cm ${ }^{-1}$ ): 3356.25 (O-H, Acid), $3070.78(\mathrm{Ar}-\mathrm{H}), 1751.42(\mathrm{C}=\mathrm{O}$, Acid), $1589.40(\mathrm{C}=\mathrm{N}$, Imine), $1512.24(\mathrm{C}=\mathrm{N}$, Pyridine $), 1319.35(\mathrm{C}-\mathrm{N}), 1226.77$ $(\mathrm{C}-\mathrm{O}) ;{ }^{1} \mathrm{H} \mathrm{NMR}\left(\delta \mathrm{ppm}, \mathrm{CDCl}_{3}\right): 4.738\left(\mathrm{~s}, 2 \mathrm{H}, \mathrm{CH}_{2}\right)$, 6.991-7.851 (m, 8H, ArH), $8.956(\mathrm{~s}, 1 \mathrm{H}, \mathrm{CH}=\mathrm{N}) ;{ }^{13} \mathrm{C}$ NMR: $\left(\delta \mathrm{ppm}, \mathrm{CDCl}_{3}\right): 65.878,114.401,114.401,116.212$,
$122.412,126.124,130.235,130.201,137.332,150.412$, $160.114,160.718,163.025,173.280 ; \mathrm{MS}(\mathrm{m} / \mathrm{z}): \mathrm{M}+1$ peak found 257.1179, ( $\mathrm{M}+1$ peak calculated 257.08). Mass fragments (m/z): 257.1179, 255.1874, 250.9812; HPLC (RT): $6.05 \mathrm{~min}$.

2-(4-((E)-(3-chlorophenylimino)methyl)phenoxy)acetic acid (CPD07). Dark yellow amorphous solid, yield 70\%, mp 184-186 ${ }^{\circ} \mathrm{C}$; IR ( $\left.\mathrm{KBr}, \mathrm{cm}^{-1}\right): 3441.12$ (O-H, Acid), $3070.78(\mathrm{Ar}-\mathrm{H}), 1697.41(\mathrm{C}=\mathrm{O}$, Acid $), 1604.83(\mathrm{C}=\mathrm{N}$, Imine), $1381.08(\mathrm{C}-\mathrm{N}), 1280.78(\mathrm{C}-\mathrm{O}), 732.97(\mathrm{C}-\mathrm{Cl}){ }^{1}{ }^{1} \mathrm{H}$ NMR $\left(\delta \mathrm{ppm}, \mathrm{CDCl}_{3}\right): 4.600\left(\mathrm{~s}, 2 \mathrm{H}, \mathrm{CH}_{2}\right), 6.564-7.478$ $(\mathrm{m}, 8 \mathrm{H}, \mathrm{ArH}), 8.255$ (s, $1 \mathrm{H}, \mathrm{CH}=\mathrm{N}) ;{ }^{13} \mathrm{C}$ NMR: $(\delta \mathrm{ppm}$, $\left.\mathrm{CDCl}_{3}\right): 67.624,114.410,114.410,120.452,122.621$, $126.110,127.458,130.221,130.221,131.252,135.694$, 154.623, 160.121, 163.021, 173.035; MS (m/z): M+1 peak found 290.0435, ( $\mathrm{M}+1$ peak calculated 290.05). Mass fragments (m/z): 290.0435, 288.0449; HPLC (RT): $12.81 \mathrm{~min}$.

2-(4-((E)-N-(5-chloro-2-hydroxyphenyl)carboximidoyl)phenoxy)acetic acid (CPD08). Pale brown amorphous solid, yield $80 \%$, mp $201-202{ }^{\circ} \mathrm{C}$; IR $\left(\mathrm{KBr}, \mathrm{cm}^{-1}\right)$ : 3394.83 (O-H, Phenolic), 3063.06 (Ar-H), 1751.42 ( $\mathrm{C}=\mathrm{O}$, Acid), $1589.40(\mathrm{C}=\mathrm{N}$, Imine), $1381.08(\mathrm{C}-\mathrm{N})$, $1226.77(\mathrm{C}-\mathrm{O}), 678.97(\mathrm{C}-\mathrm{Cl}) ;{ }^{1} \mathrm{H}$ NMR $(\delta \mathrm{ppm}, \mathrm{DMSO}$ $\left.\mathrm{D}_{6}\right): 4.795\left(\mathrm{~s}, 2 \mathrm{H}, \mathrm{CH}_{2}\right), 6.854-7.949(\mathrm{~m}, 7 \mathrm{H}, \mathrm{ArH}), 8.596$ $(\mathrm{s}, 1 \mathrm{H}, \mathrm{CH}=\mathrm{N}) ;{ }^{13} \mathrm{C}$ NMR: $\left(\delta \mathrm{ppm}, \mathrm{DMSO} \mathrm{D}_{6}\right): 52.303$, 52.357, 65.060, 65.113, 65.174, 115.107, 115.160, 115.456, $115.509,115.972,117.649,119.220,123.197,123.318$, $126.566,129.837,130.489,131.294,132.113,139.854$, $150.478,160.533,160.981,163.121,169.988,170.231$, 191.707; MS (m/z): $M+1$ peak found 306.5956, $(M+1$ peak calculated 306.05). Mass fragments (m/z): 306.5956, 305.5344, 305.8690; HPLC (RT): $12.88 \mathrm{~min}$.

2-(4-((1E)-(2-(2,4-dinitrophenyl)hydrazin-1-ylidene) methyl)phenoxy)acetic acid (CPD09). Orange amorphous solid, yield $82 \%$, mp $193-195^{\circ} \mathrm{C}$; IR $\left(\mathrm{KBr}, \mathrm{cm}^{-1}\right): 3618.58$ (N-H), $3294.53(\mathrm{O}-\mathrm{H}$, Acid), $3109.35(\mathrm{Ar}-\mathrm{H}), 1728.28$ ( $\mathrm{C}=\mathrm{O}$, Acid), $1604.83(\mathrm{C}=\mathrm{N}$, Imine $), 1504.53\left(\mathrm{NO}_{2}\right)$, $1334.78(\mathrm{C}-\mathrm{N}), 1257.63(\mathrm{C}-\mathrm{O}) ;{ }^{1} \mathrm{H}$ NMR $(\delta \mathrm{ppm}, \mathrm{DMSO}$ $\left.\mathrm{D}_{6}\right): 4.552\left(\mathrm{~s}, 2 \mathrm{H}, \mathrm{CH}_{2}\right), 6.870-8.241(\mathrm{~m}, 7 \mathrm{H}, \mathrm{ArH}), 8.962$ $(\mathrm{s}, 1 \mathrm{H}, \mathrm{CH}=\mathrm{N}), 11.327(\mathrm{~s}, 1 \mathrm{H}, \mathrm{NH}),{ }^{13} \mathrm{C}$ NMR: $(\delta \mathrm{ppm}$, DMSO D $)$ : 65.037, 77.460, 77.786, 77.983, 78.105, $115.047,116.891,123.311,126.983,129.108,129.268$, 129.662, 144.916, 148.550, 160.062, 173.155; MS (m/z): $M+1$ peak found 361.1061, $(M+1$ peak calculated 361.07). Mass fragments $(\mathrm{m} / \mathrm{z})$ : 361.1061, 351.1051, 349.2133; HPLC (RT): $8.56 \mathrm{~min}$.

2-(4-((1E)-((pyridin-4-ylformamido)imino)methyl)phenoxy)acetic acid (CPD10). White amorphous solid, yield 80\%, mp 200-202 ${ }^{\circ} \mathrm{C}$; IR $\left(\mathrm{KBr}, \mathrm{cm}^{-1}\right): 3572.29(\mathrm{~N}-\mathrm{H})$, 3394.83 (O-H, Acid), $3039.91(\mathrm{Ar}-\mathrm{H}), 1743.71(\mathrm{C}=\mathrm{O}$, Acid), 1666.55 ( $\mathrm{C}=\mathrm{O}$, Amide), $1604.83(\mathrm{C}=\mathrm{N}$, Imine), $1296.21(\mathrm{C}-\mathrm{N}), 1249.91(\mathrm{C}-\mathrm{O}) ;{ }^{1} \mathrm{HNMR}\left(\delta \mathrm{ppm}, \mathrm{CDCl}_{3}\right)$ : 
$4.533\left(\mathrm{~s}, 2 \mathrm{H}, \mathrm{CH}_{2}\right), 6.831-8.304(\mathrm{~m}, 8 \mathrm{H}, \mathrm{ArH}), 8.653$ $(\mathrm{s}, 1 \mathrm{H}, \mathrm{CH}=\mathrm{N}), 11.547(\mathrm{~s}, 1 \mathrm{H}, \mathrm{NH}) ;{ }^{13} \mathrm{C} \mathrm{NMR}:(\delta \mathrm{ppm}$, $\left.\mathrm{CDCl}_{3}\right)$ : 67.037, 77.780, 77.786, 77.883, 77.905, 126.311, $129.983,140.108,143.268,149.662,149.916,160.050$, 160.062, 173.155;MS (m/z): $\mathrm{M}+1$ peak found 300.1331, $(\mathrm{M}+1$ peak calculated 300.09$)$. Mass fragments $(\mathrm{m} / \mathrm{z})$ : 300.1331, 298.0772; HPLC (RT): 2.95 min.

2-(4-((E)-(4-ethoxyphenylimino)methyl)phenoxy)acetic acid (CPD11). Off white amorphous solid, yield 81\%, mp 186-188 ${ }^{\circ} \mathrm{C}$; IR (KBr, cm $\left.{ }^{-1}\right): 3394.83$ (O-H, Acid), $3070.78(\mathrm{Ar}-\mathrm{H}), 1651.12(\mathrm{C}=\mathrm{O}$, Acid $), 1604.83(\mathrm{C}=\mathrm{N}$, Imine), $1350.22(\mathrm{C}-\mathrm{N}), 1242.20(\mathrm{C}-\mathrm{O}) ;{ }^{1} \mathrm{H}$ NMR $(\delta \mathrm{ppm}$, DMSO D $): 1.288\left(\mathrm{t}, 3 \mathrm{H}, \mathrm{CH}_{3}\right), 3.918\left(\mathrm{q}, 2 \mathrm{H}, \mathrm{CH}_{2}\right), 4.567$ (s, 2H, $\mathrm{CH}_{2}$ ), 6.474-7.736 (m, 8H, ArH), $8.333(\mathrm{~s}, 1 \mathrm{H}$, $\mathrm{CH}=\mathrm{N}) ;{ }^{13} \mathrm{C}$ NMR: $\left(\delta \mathrm{ppm}, \mathrm{DMSO} \mathrm{D}_{6}\right): 63.590,63.891$, 65.098, 78.044, 78.371, 78.368, 78.697, 114.826, 115.001, 115.623, 115.876, 122.104, 130.156, 144.749, 157.217, 157.346; MS (m/z): $M+1$ peak found 300.2240, $(M+1$ peak calculated 300.12). Mass fragments (m/z): 300.2240, 299.2101, 297.0445; HPLC (RT): 7.43 min.

2-(4-((E)-(4-aminophenylimino)methyl)phenoxy)acetic acid (CPD12). White amorphous solid, yield 80\%, mp 196-198 ${ }^{\circ} \mathrm{C}$; IR (KBr, cm $\left.{ }^{-1}\right): 3502.85$ (N-H, Amine), 3394.83 (O-H, Acid), $3017.23(\mathrm{Ar}-\mathrm{H}), 1651.20(\mathrm{C}=\mathrm{O}$, Acid), $1604.83(\mathrm{C}=\mathrm{N}$, Imine), $1330.51(\mathrm{C}-\mathrm{N}), 1242.20$ $(\mathrm{C}-\mathrm{O}) ;{ }^{1} \mathrm{H}$ NMR $\left(\delta \mathrm{ppm}, \mathrm{CDCl}_{3}\right): 4.642\left(\mathrm{~s}, 2 \mathrm{H}, \mathrm{CH}_{2}\right)$, 6.545-8.039 (m, 8H, ArH), $8.379(\mathrm{~s}, 1 \mathrm{H}, \mathrm{CH}=\mathrm{N}) ;{ }^{13} \mathrm{C}$ NMR: $\left(\delta \mathrm{ppm}, \mathrm{CDCl}_{3}\right): 67.124,77.784,77.784,79.883$, $79.905,125.311,125.383,129.108,136.268,145.662$, 146.916, 160.140, 163.062, 173.051; MS (m/z): $\mathrm{M}+1$ peak found 271.1371, $(\mathrm{M}+1$ peak calculated 271.10). Mass fragments (m/z): 271.1371, 270.9644, 270.1306; HPLC (RT): $3.06 \mathrm{~min}$.

2-(2-methoxy-4-((E)-(phenylimino)methyl)phenoxy)acetic acid (CPD13). Yellow amorphous solid, yield 79\%, mp 194-196 ${ }^{\circ} \mathrm{C}$; IR (KBr, cm ${ }^{-1}$ ): 3309.96 (OH, Acid), 3024.48 (ArH), $1675.20(\mathrm{C}=\mathrm{O}$, Acid $), 1597.11(\mathrm{C}=\mathrm{N}$, Imine $)$, $1265.35(\mathrm{C}-\mathrm{N}), 1226.77(\mathrm{C}-\mathrm{O}) ;{ }^{1} \mathrm{H}$ NMR $\left(\delta \mathrm{ppm}, \mathrm{CDCl}_{3}\right)$ : $3.796\left(\mathrm{~s}, 3 \mathrm{H}, \mathrm{OCH}_{3}\right), 4.496\left(\mathrm{~s}, 2 \mathrm{H}, \mathrm{CH}_{2}\right), 6.635-7.598$ $(\mathrm{m}, 8 \mathrm{H}, \mathrm{ArH}), 9.050(\mathrm{~s}, 1 \mathrm{H}, \mathrm{CH}=\mathrm{N}) ;{ }^{13} \mathrm{C} \mathrm{NMR}:(\delta \mathrm{ppm}$, $\left.\mathrm{CDCl}_{3}\right):$ 56.285, 67.912, 82.354, 83.381, 89.878, 89.999, $111.326,121.664,127.128,132.311,133.950,145.422$, 149.313, 150.621, 160.681, 174.838; MS (m/z): $\mathrm{M}+1$ peak found 286.1418, $(\mathrm{M}+1$ peak calculated 286.29). Mass fragments $(\mathrm{m} / \mathrm{z}): 286.1418,263.1089,233.0761$; HPLC (RT): $9.51 \mathrm{~min}$.

2-(4-((E)-(4-methoxyphenylimino)methyl)-2-methoxyphenoxy)acetic acid (CPD14). Yellow amorphous solid, yield $75 \%$, mp $193-195{ }^{\circ} \mathrm{C}$; IR $\left(\mathrm{KBr}, \mathrm{cm}^{-1}\right)$ : 3394.83 (O-H, Acid), 3070.78 (Ar-H), 1666.55 (C=O, Acid), $1597.11(\mathrm{C}=\mathrm{N}$, Imine $), 1275.35(\mathrm{C}-\mathrm{N}), 1226.20(\mathrm{C}-\mathrm{O}){ }^{1}{ }^{1} \mathrm{H}$ NMR $\left(\delta\right.$ ppm, $\left.\mathrm{CDCl}_{3}\right): 3.775\left(\mathrm{~s}, 3 \mathrm{H}, \mathrm{OCH}_{3}\right), 3.940(\mathrm{~s}, 3 \mathrm{H}$, $\left.\mathrm{OCH}_{3}\right), 4.782\left(\mathrm{~s}, 2 \mathrm{H}, \mathrm{CH}_{2}\right), 6.657-7.607$ (m, 7H, ArH), $8.371(\mathrm{~s}, 1 \mathrm{H}, \mathrm{CH}=\mathrm{N}){ }^{13} \mathrm{C}$ NMR: $\left(\delta \mathrm{ppm}, \mathrm{CDCl}_{3}\right): 55.885$, 56.220, 67.856, 82.364, 83.364, 84.578, 84.580, 122.664, $124.128,124.221,130.311,143.950,145.422,149.313$, 158.621, 160.681, 174.838; MS (m/z): $M+1$ peak found 317.1613, $(\mathrm{M}+1$ peak calculated 316.11). Mass fragments (m/z): 317.1613, 316.1502, 315.0157; HPLC (RT): $6.51 \mathrm{minY}$

2-(4-((E)-N-(4-hydroxyphenyl)carboximidoyl)-2-methoxyphenoxy)acetic acid (CPD15). Yellowish orange amorphous solid, yield $85 \%$, mp $198-200{ }^{\circ} \mathrm{C}$; IR (KBr, $\left.\mathrm{cm}^{-1}\right)$ : 3410.26 (O-H, Phenol), 3178.79 (O-H, Acid), $3078.49(\mathrm{Ar}-\mathrm{H}), 1666.55(\mathrm{C}=\mathrm{O}$, Acid $), 1597.11(\mathrm{C}=\mathrm{N}$, Imine), $1273.06(\mathrm{C}-\mathrm{N}), 1219.05(\mathrm{C}-\mathrm{O}){ }^{1} \mathrm{H}$ NMR $(\delta$ ppm, $\left.\mathrm{CDCl}_{3}\right): 3.849\left(\mathrm{~s}, 3 \mathrm{H}, \mathrm{OCH}_{3}\right), 4.587\left(\mathrm{~s}, 2 \mathrm{H}, \mathrm{CH}_{2}\right)$, 6.710-8.282 (m, 7H, ArH), 8.884 (s, $1 \mathrm{H}, \mathrm{CH}=\mathrm{N}) ;{ }^{13} \mathrm{C}$ NMR: $\left(\delta\right.$ ppm, $\left.\mathrm{CDCl}_{3}\right): 56.212,67.895,114.364,115.364$, $116.578,116.580,122.564,125.128,126.221,130.311$, 130.350, 149.422, 152.313, 160.621, 164.681, 173.938; MS $(\mathrm{m} / \mathrm{z}): \mathrm{M}+1$ peak found $301.0727,(\mathrm{M}+1$ peak calculated 302.10). Mass fragments (m/z): 301.0727, 300.0725; HPLC (RT): 10.86 min.

2-(2-methoxy-4-((E)-(pyridin-2-ylimino)methyl)phenoxy)acetic acid (CPD16). White amorphous solid, yield 80\%, mp 187-189 ${ }^{\circ} \mathrm{C}$; IR $\left(\mathrm{KBr}, \mathrm{cm}^{-1}\right)$ : $3425.69(\mathrm{O}-\mathrm{H}$, Acid), $3078.20(\mathrm{Ar}-\mathrm{H}), 1690.55$ (C=O, Acid), 1604.83 $\left(\mathrm{C}=\mathrm{N}\right.$, Imine), $1273.06(\mathrm{C}-\mathrm{N}), 1218.05(\mathrm{C}-\mathrm{O}) ;{ }^{1} \mathrm{H}$ NMR $\left(\delta \mathrm{ppm}, \mathrm{CDCl}_{3}\right): 3.817\left(\mathrm{~s}, 3 \mathrm{H}, \mathrm{OCH}_{3}\right), 4.404\left(\mathrm{~s}, 2 \mathrm{H}, \mathrm{CH}_{2}\right)$, 6.414-7.829 (m, 7H, ArH), 8.884 (s, $1 \mathrm{H}, \mathrm{CH}=\mathrm{N}) ;{ }^{13} \mathrm{C}$ NMR: $\left(\delta\right.$ ppm, $\left.\mathrm{CDCl}_{3}\right): 56.202,67.915,114.464,115.384$, $116.618,122.464,122.521,127.128,137.311,149.922$, 150.413, 152.621, 160.181, 160.712, 173.895;MS (m/z): $\mathrm{M}+1$ peak found 287.4666, $(\mathrm{M}+1$ peak calculated 287.10). Mass fragments (m/z): 287.4666, 278.4613, 271.9437; HPLC (RT): $0.50 \mathrm{~min}$.

2-(4-((E)-N-(5-chloro-2-hydroxyphenyl)carboximidoyl)2-methoxyphenoxy)acetic acid (CPD17). Pale Yellow crystalline solid, yield $80 \%, \mathrm{mp} 193-195{ }^{\circ} \mathrm{C}$; IR (KBr, $\mathrm{cm}^{-1}$ ): 3525.99 (O-H, Phenol), 3394.83 (O-H, Acid), $3078.20(\mathrm{Ar}-\mathrm{H}), 1650.12(\mathrm{C}=\mathrm{O}$, Acid $), 1604.83(\mathrm{C}=\mathrm{N}$, Imine), $1265.35(\mathrm{C}-\mathrm{N}), 1226.77(\mathrm{C}-\mathrm{O}), 709.83$ (C$\mathrm{Cl}) ;{ }^{1} \mathrm{H}$ NMR $\left(\delta \mathrm{ppm}, \mathrm{CDCl}_{3}\right): 3.827\left(\mathrm{~s}, 3 \mathrm{H}, \mathrm{OCH}_{3}\right)$, $4.443\left(\mathrm{~s}, 2 \mathrm{H}, \mathrm{CH}_{2}\right), 6.771-7.571(\mathrm{~m}, 6 \mathrm{H}, \mathrm{ArH}), 8.357$ (s, $1 \mathrm{H}, \mathrm{CH}=\mathrm{N}) ;{ }^{13} \mathrm{C}$ NMR: $\left(\delta \mathrm{ppm}, \mathrm{CDCl}_{3}\right): 56.212,67.905$, $114.489,115.584,117.518,119.864,122.525,126.128$, $127.311,130.712,132.652,149.922,152.113,159.621$, 164.612, 173.945; MS (m/z): $\mathrm{M}+1$ peak found 336.0919, $(\mathrm{M}+1$ peak calculated 336.06). Mass fragments $(\mathrm{m} / \mathrm{z})$ : 336.0919, 335.0671, 334.0759. HPLC (RT): $7.12 \mathrm{~min}$.

2-(2-methoxy-4-((1E)-(2-phenylhydrazin-1-ylidene) methyl)phenoxy)acetic acid (CPD18). White amorphous solid, yield $79 \%$, mp $180-182^{\circ} \mathrm{C}$; IR $\left(\mathrm{KBr}, \mathrm{cm}^{-1}\right): 3502.85$ (N-H), 3394.83 (O-H, Acid), $3032.20($ Ar-H), 1653.41 (C=O, Acid), $1597.11(\mathrm{C}=\mathrm{N}$, Imine), $1265.35(\mathrm{C}-\mathrm{N})$, 
$1225.77(\mathrm{C}-\mathrm{O}){ }^{1}{ }^{1} \mathrm{H}$ NMR $\left(\delta \mathrm{ppm}, \mathrm{CDCl}_{3}\right): 3.809$ (s, 3H, $\left.\mathrm{OCH}_{3}\right), 4.463\left(\mathrm{~s}, 2 \mathrm{H}, \mathrm{CH}_{2}\right), 6.628-7.741$ (m, 9H, ArH), $8.282(\mathrm{~s}, 1 \mathrm{H}, \mathrm{CH}=\mathrm{N}),{ }^{13} \mathrm{C}$ NMR: $\left(\delta \mathrm{ppm}, \mathrm{CDCl}_{3}\right): 56.236$, $67.865,114.499,115.484,116.318,116.321,118.864$, $122.515,127.128,129.611,129.625,143.023,143.152$, 149.922, 152.123, 173.845;MS (m/z): $\mathrm{M}+1$ peak found 301.1485, $(\mathrm{M}+1$ peak calculated 301.11). Mass fragments (m/z): 301.1485, 298.0772; HPLC (RT): 7.56 min.

2-(4-((1E)-(2-(2,4-bis(hydroxynitroso)phenyl)hydrazin-1-ylidene)methyl)-2-methoxyphenoxy)acetic acid (CPD19). Orange red amorphous solid, yield 79\%, mp 189-192 ${ }^{\circ} \mathrm{C}$; IR $\left(\mathrm{KBr}, \mathrm{cm}^{-1}\right): 3525.99(\mathrm{~N}-\mathrm{H}), 3279.10$ (O-H, Acid), 3086.21 (Ar-H), 1749.41 (C=O, Acid), $1620.26\left(\mathrm{C}=\mathrm{N}\right.$, Imine), $1504.53\left(\mathrm{NO}_{2}\right), 1327.07(\mathrm{C}-\mathrm{N})$, $1219.05(\mathrm{C}-\mathrm{O}) ;{ }^{1} \mathrm{H}$ NMR $\left(\delta \mathrm{ppm}, \mathrm{CDCl}_{3}\right): 3.865(\mathrm{~s}$, $\left.3 \mathrm{H}, \mathrm{OCH}_{3}\right), 4.584\left(\mathrm{~s}, 2 \mathrm{H}, \mathrm{CH}_{2}\right), 6.766-8.267(\mathrm{~m}, 6 \mathrm{H}$, $\mathrm{ArH}), 8.953(\mathrm{~s}, 1 \mathrm{H}, \mathrm{CH}=\mathrm{N}), 11.369(\mathrm{~s}, 1 \mathrm{H},-\mathrm{NH}) ;{ }^{13} \mathrm{C}$ NMR: $\left(\delta \mathrm{ppm}, \mathrm{CDCl}_{3}\right)$ : 60.825, 76.622, 82.354, 82.681, $82.878,82.999,114.326,118.097,121.664,127.128$, $132.311,133.950,134.422,142.313,149.621,153.681$, 154.561, 154.758, 174.838; MS (m/z): $\mathrm{M}+1$ peak found 391.1217, $(\mathrm{M}+1$ peak calculated 391.08). Mass fragments (m/z): 391.1217, 349.2133; HPLC (RT): $8.42 \mathrm{~min}$.

2-(2-methoxy-4-((1E)-((pyridin-4-ylformamido)imino) methyl)phenoxy)acetic acid (CPD20). Yellow amorphous solid, yield $71 \%$, mp $184-186{ }^{\circ} \mathrm{C}$; IR $\left(\mathrm{KBr}, \mathrm{cm}^{-1}\right): 3487.42$ $(\mathrm{N}-\mathrm{H}), 3240.52(\mathrm{O}-\mathrm{H}$, Acid), $3078.49(\mathrm{Ar}-\mathrm{H}), 1743.71$ ( $\mathrm{C}=\mathrm{O}$, Amide), $1666.55(\mathrm{C}=\mathrm{O}$, Acid $), 1604.83(\mathrm{C}=\mathrm{N}$, Imine), $1265.35(\mathrm{C}-\mathrm{N}), 1226.77(\mathrm{C}-\mathrm{O}) ;{ }^{1} \mathrm{H}$ NMR $(\delta \mathrm{ppm}$, $\left.\mathrm{CDCl}_{3}\right): 3.820\left(\mathrm{~s}, 3 \mathrm{H}, \mathrm{OCH}_{3}\right), 4.525\left(\mathrm{~s}, 2 \mathrm{H}, \mathrm{CH}_{2}\right), 6.726-$ $8.284(\mathrm{~m}, 7 \mathrm{H}, \mathrm{ArH}), 8.657(\mathrm{~s}, 1 \mathrm{H}, \mathrm{CH}=\mathrm{N}), 11.662(\mathrm{~s}, 1 \mathrm{H}$, $\mathrm{NH}) ;{ }^{13} \mathrm{C}$ NMR: $\left(\delta \mathrm{ppm}, \mathrm{CDCl}_{3}\right): 56.212,67.954,114.421$, $115.212,122.545,122.854,122.865,127.121,140.912$, $143.032,149.832,149.832,149.954,152.121,163.423$, 173.323; MS $(\mathrm{m} / \mathrm{z}): \mathrm{M}+1$ peak found 330.1415, $(\mathrm{M}+1$ peak calculated 330.10); HPLC (RT): 3.09 min.

2-(4-((E)-(3-methoxyphenylimino)methyl)-2-methoxyphenoxy)acetic acid (CPD21). Green amorphous solid, yield $70 \%$, mp $238-240{ }^{\circ} \mathrm{C}$; IR $\left(\mathrm{KBr}, \mathrm{cm}^{-1}\right)$ : 3363.97 (O-H, Acid), $3063.06(\mathrm{Ar}-\mathrm{H}), 1705.10(\mathrm{C}=\mathrm{O}$, Acid $)$, $1604.83\left(\mathrm{C}=\mathrm{N}\right.$, Imine), $1265.35(\mathrm{C}-\mathrm{N}), 1211.34(\mathrm{C}-\mathrm{O}) ;{ }^{1} \mathrm{H}$ NMR $\left(\delta \mathrm{ppm}, \mathrm{CDCl}_{3}\right): 3.524\left(\mathrm{~s}, 3 \mathrm{H}, \mathrm{OCH}_{3}\right), 3.597(\mathrm{~s}, 3 \mathrm{H}$, $\left.\mathrm{OCH}_{3}\right), 4.450\left(\mathrm{~s}, 2 \mathrm{H}, \mathrm{CH}_{2}\right), 6.377-7.625(\mathrm{~m}, 8 \mathrm{H}, \mathrm{ArH})$, $8.357(\mathrm{~s}, 1 \mathrm{H}, \mathrm{CH}=\mathrm{N}) ;{ }^{13} \mathrm{C}$ NMR: $\left(\delta \mathrm{ppm}, \mathrm{CDCl}_{3}\right): 55.912$, $56.212, \quad 67.954,108.312,112.875,114.421,115.412$, $122.545,127.185,131.165,149.912,152.032,154.232$, 160.123, 162.023, 173.723;MS (m/z): $\mathrm{M}+1$ peak found 316.1502, $(\mathrm{M}+1$ peak calculated 316.11); HPLC (RT): $4.63 \mathrm{~min}$.

2-(4-((E)-(4-ethoxyphenylimino)methyl)-2-methoxyphenoxy)acetic acid (CPD22). White amorphous solid, yield 80\%, mp 197-199 ${ }^{\circ} \mathrm{C}$; IR (KBr, cm $\left.{ }^{-1}\right)$ : $3425.69(\mathrm{O}-\mathrm{H}$, Acid), 3070.78 (Ar-H), 1666.55 ( $\mathrm{C}=\mathrm{O}$, Acid), 1597.11
$(\mathrm{C}=\mathrm{N}, \quad$ Imine $), \quad 1280.78 \quad(\mathrm{C}-\mathrm{N}), \quad 1257.63 \quad(\mathrm{C}-\mathrm{O}) ;{ }^{1} \mathrm{H}$ NMR ( $\delta$ ppm, DMSO D $): 1.307\left(\mathrm{t}, 3 \mathrm{H}, \mathrm{CH}_{3}\right), 3.819(\mathrm{~s}$, $\left.3 \mathrm{H}, \mathrm{OCH}_{3}\right), 3.918\left(\mathrm{q}, 2 \mathrm{H}, \mathrm{CH}_{2}\right), 4.569\left(\mathrm{~s}, 2 \mathrm{H}, \mathrm{CH}_{2}\right)$, 6.784-7.776 (m, 7H, ArH), $8.303(\mathrm{~s}, 1 \mathrm{H}, \mathrm{CH}=\mathrm{N}) ;{ }^{13} \mathrm{C}$ NMR: $\left(\delta \mathrm{ppm}\right.$, DMSO $\left.\mathrm{D}_{6}\right): 55.999,63.656,65.826$, $110.342,112.990,115.335,122.620,123.599,130.231$, 144.764, 149.507, 150.546, 157.338, 158.228, 170.489, 172.386; MS (m/z): $\mathrm{M}+1$ peak found 330.1653, $(\mathrm{M}+1$ peak calculated 330.13). Mass fragments (m/z): 330.1653, 328.2463, 327.2336; HPLC (RT): $7.56 \mathrm{~min}$.

2-(4-((E)-(4-aminophenylimino)methyl)-2-methoxyphenoxy)acetic acid (CPD23). Dark red amorphous solid, yield $80 \%$, mp $201-203{ }^{\circ} \mathrm{C}$; IR $\left(\mathrm{KBr}, \mathrm{cm}^{-1}\right)$ : 3448.84 (N-H, Amine), $3340.82(\mathrm{O}-\mathrm{H}$, Acid), $3070.78(\mathrm{Ar}-\mathrm{H})$, $1666.55(\mathrm{C}=\mathrm{O}$, Acid $), 1604.83(\mathrm{C}=\mathrm{N}$, Imine $), 1280.78$ $(\mathrm{C}-\mathrm{N}), 1219.06(\mathrm{C}-\mathrm{O}) ;{ }^{1} \mathrm{H}$ NMR $\left(\delta \mathrm{ppm}, \mathrm{CDCl}_{3}\right): 3.841$ $\left(\mathrm{s}, 3 \mathrm{H}, \mathrm{OCH}_{3}\right), 4.644\left(\mathrm{~s}, 2 \mathrm{H}, \mathrm{CH}_{2}\right), 6.564-7.674(\mathrm{~m}, 7 \mathrm{H}$, ArH), $8.352(\mathrm{~s}, 1 \mathrm{H}, \mathrm{CH}=\mathrm{N}) ;{ }^{13} \mathrm{C}$ NMR: $\left(\delta \mathrm{ppm}, \mathrm{CDCl}_{3}\right)$ : $56.212,67.954,114.412,115.475,117.621,122.512$, $123.145,127.185,143.265,146.912,149.932,152.132$, $160.189,173.874$; MS (m/z): $\mathrm{M}+1$ peak found 301.1713, $(\mathrm{M}+1$ peak calculated 301.11$)$. Mass fragments $(\mathrm{m} / \mathrm{z})$ : 301.1713, 299.2177; HPLC (RT): 10.83 min.

2-(4-((E)-(3-aminophenylimino)methyl)-2-methoxyphenoxy)acetic acid (CPD24). Dark yellow amorphous solid, yield 70\%, mp 186-188 ${ }^{\circ} \mathrm{C}$; IR $\left(\mathrm{KBr}, \mathrm{cm}^{-1}\right): 3394.83(\mathrm{~N}-\mathrm{H}$, Amine), 3340.82 (O-H, Acid), 3055.35 (Ar-H), 1651.12 $(\mathrm{C}=\mathrm{O}$, Acid $), 1589.40(\mathrm{C}=\mathrm{N}$, Imine $), 1265.35(\mathrm{C}-\mathrm{N})$, $1219.05(\mathrm{C}-\mathrm{O}) ;{ }^{1} \mathrm{H}$ NMR $\left(\delta \mathrm{ppm}, \mathrm{CDCl}_{3}\right): 3.820(\mathrm{~s}, 3 \mathrm{H}$, $\left.\mathrm{OCH}_{3}\right), 4.678\left(\mathrm{~s}, 2 \mathrm{H}, \mathrm{CH}_{2}\right), 6.905-7.458(\mathrm{~m}, 7 \mathrm{H}, \mathrm{ArH})$, $8.510(\mathrm{~s}, 1 \mathrm{H}, \mathrm{CH}=\mathrm{N}),{ }^{13} \mathrm{C}$ NMR: $\left(\delta \mathrm{ppm}, \mathrm{CDCl}_{3}\right): 56.212$, $67.954,107.712,112.375,114.321,114.812,115.445$, $122.585,127.165,130.912,149.745,149.932,152.132$, 160.189, 173.923;MS (m/z): $\mathrm{M}+1$ peak found 301.1485, $(\mathrm{M}+1$ peak calculated 301.11$)$. Mass fragments $(\mathrm{m} / \mathrm{z})$ : 301.1485, 299.2177, 283.2071; HPLC (RT): 0.70 min.

\section{Cytotoxic assay}

Procedure adopted for cytotoxic assay was MTT assay by using 3T3-L1 cell lines. Tests were performed in 96-well plates. Cells were seeded (10,000 cells/well) and grown to maturation. Mature adipocytes were incubated with either $0.2 \%$ dimethylsulfoxide (DMSO) or the test samples (250$3.125 \mu \mathrm{g} / \mathrm{ml}$ ) for $48 \mathrm{~h}$. A cell viability assay was performed as per the manufacturer's instructions. A total of $50 \mu \mathrm{l}$ of the MTT solution $(5 \mathrm{mg} / \mathrm{ml})$ was added to each well and the plates were incubated for $3 \mathrm{~h}$ at $37^{\circ} \mathrm{C}$. After incubation, $200 \mu \mathrm{l}$ of DMSO was added to the wells followed by gentle shaking to solubilise the formazan dye. Absorbance was read at $560 \mathrm{~nm}$ using a microplate reader to determine the formazan concentration, which is proportional to the 
number of live cells [36]. Surviving cell fraction was calculated according to the following equation:

$$
\text { Cell viability }(\%)=\left(\mathrm{A}_{\mathrm{s}} / \mathrm{A}_{\mathrm{c}}\right) \times 100
$$

where, $A_{s}$ is the absorbance of the sample and $A_{c}$ is the absorbance of the control, and the cytotoxicity is expressed as a percentage relative to control cells (without test sample supplementation).

\section{Glucose uptake assay}

Monolayer of L-6 cells was maintained at sub confluent conditions in growth media containing DMEM with $4.5 \mathrm{~g} / \mathrm{l}$ glucose, $100 \mathrm{U} / \mathrm{ml}$ penicillin, $100-\mu \mathrm{g} / \mathrm{ml}$ streptomycin, and $10 \%$ fetal bovine serum. Cells were maintained in a humidified $37{ }^{\circ} \mathrm{C}$ incubator with ambient oxygen and $5 \% \mathrm{CO}_{2}$. Cells were maintained in continuous passage by trypsinization of sub confluent cultures using TPVG solution [38].

Cells were cultured on 24 well plates and incubated for $48 \mathrm{~h}$ at $37{ }^{\circ} \mathrm{C}$ in $\mathrm{CO}_{2}$ incubator. When semi confluent monolayer was formed the culture were renewed with serum free DMEM containing 0.2\% Bovine serum albumin (BSA) and incubated for $18 \mathrm{~h}$ at $37{ }^{\circ} \mathrm{C}$ in $\mathrm{CO}_{2}$ incubator. After $18 \mathrm{~h}$ media was discarded and cells were washed with KRP buffer once. The cells were then treated with Insulin and test compounds. Consequently glucose solution $(1 \mathrm{M})$ was added and incubated for half an hour. Supernatant was collected for glucose estimation and glucose uptake was terminated by washing the cells three times with $1 \mathrm{ml}$ ice-cold KRP buffer. Subsequent freezing and thawing three times lysed all cells. Cell lysate was collected for glucose estimation [39, 40]. Glucose uptake was calculated as the difference between the initial and final glucose content in the incubated medium by GODPOD method [57, 58]. $10 \mu \mathrm{l}$ of sample was mixed with $1 \mathrm{ml}$ of reagent (GOD-POD reagent) and incubated for $10 \mathrm{~min}$ at $37{ }^{\circ} \mathrm{C}$. The absorbance of standard $\left(\mathrm{A}_{\text {standard }}\right)$ and test compounds $\left(\mathrm{A}_{\text {sample }}\right)$ against blank was measured at $505 \mathrm{~nm}$. Formula is;

$$
\begin{aligned}
& \text { Glucose concentration }(\mathrm{mg} / \mathrm{dl}) \\
& =\left(\mathrm{A}_{\text {sample }} / \mathrm{A}_{\text {standard }}\right) \times 100
\end{aligned}
$$

\section{D-QSAR study}

CoMSIA is a powerful and established tool for building 3D-QSAR models that can be applied to drug design [46]. The regular protocol for CoMSIA study and threedimensional structure building and all the modelling were carried out using the SYBYL-X 2.1.1 program package and the conformations of the compounds in the training and test sets were generated using the systematic conformational search method implemented in SYBYL-X 2.1.1. The molecules were drawn and analysed for conformation to ensure that all the molecules possessing same E configuration and with same scaffold arrangement. Energy minimization was affected using the MMFF94 s [44] with a distance dependent dielectric and the Powell conjugate gradient algorithm with a convergence criterion of $0.001 \mathrm{kcal} / \mathrm{mol}$. Partial atomic charges were calculated by the Gasteiger-Huckel method [47]. Consequently, all the 24 substituted phenoxy acetic acids were aligned according to their common substructure. Molecular alignment was affected with the field fit alignment [59] method function of SYBYL. After consistently aligning the molecules within a lattice that extended $4 \AA$ units beyond the aligned molecules in all directions with a grid space size of $2 \AA$, a probe sp3 carbon atom with a net charge of +1 and van der Waals radius of $1.52 \AA$ was employed. The five similarity indices in CoMSIA, i.e., steric, electrostatic, hydrophobic, $\mathrm{H}$-bond donor, and $\mathrm{H}$-bond acceptor descriptors were calculated and the fields generated were scaled by the CoMSIA-STD method in SYBYL-X 2.1.1. Here, steric indices are related to the third power of the atomic radii, the electrostatic descriptors are derived from the atomic partial charges, the hydrophobic fields are derived from the atom-based parameters, and the $\mathrm{H}$-bond donor and acceptor indices are obtained by a rule-based method based on the experimental results. In optimizing the CoMSIA performance, the most important parameter is how to combine the five fields in the CoMSIA model. To choose the optimal result, we systematically altered the combination of fields and chose the value that gave the best non-cross-validation, the smallest errors, and the largest $\mathrm{F}$ (Fischer's covariance ratio) value. Finally, the model generated by combining the steric, electrostatic, hydrophobic, and hydrogen bond acceptor and hydrogen bond donor fields was selected as the best CoMSIA model, and the contours were analysed using this model. To derive the 3D-QSAR models, the CoMSIA descriptors were used as independent variables with the respective activity (lnGU) value as a dependent variable. Partial least-squares (PLS) [59] regression analysis was performed with the standard protocol implemented in the SYBYL package. The predictive ability of the models was evaluated by leave-one-out (LOO) cross-validation. The developed model was further evaluated by predicting activities of the external test set compounds.

\section{Conclusion}

The present work led to the development of novel glitazones in the lights of concepts of rational design using various computational techniques. Based on the pharmacophore modelling results, we decided docking protocols 
keeping PPAR $\gamma$ as target protein to virtually screen the library of glitazones and finally subjected for molecular dynamic simulation studies. The molecular dynamic simulation for best protein-ligand complex helped to comprehend the dynamic behaviour of glitazones in physiological environment. CPD03, 07, 08, 18, 19, 21 and $\mathbf{2 4}$ are the candidate glitazones to investigate further as they produce significant glucose uptake activity. The structure activity relationship was derived via CoMSIA model considering glucose uptake activity, thereby indirectly correlating reported glitazones as PPAR $\gamma$ agonists.

\section{Authors' Contributions \\ All authors listed have made a substantial, direct and intellectual contribution to the work, and approved it for publication. SM carried out the computa- tional studies, experimental work, analyzed the data and documented. LD and BRP supervised the research project. AG and AW carried out the biological evaluation. SM and PP revised the final manuscript. All authors read and approved the final manuscript.}

\section{Author details}

1 Department of Pharmaceutical Chemistry, JSS College of Pharmacy, JSS Academy of Higher Education and Research, Mysuru 570 015, India. ${ }^{2}$ Department of Pharmaceutical Biotechnology, JSS College of Pharmacy, Ootacamund 643 001, India. ${ }^{3}$ Bioanalytical Division, Biocon Ltd, Bengaluru 560 100, India.

\section{Competing interest}

The authors declare they have no competing interests.

\section{Funding}

There are no specific funding for the study.

\section{Publisher's Note}

Springer Nature remains neutral with regard to jurisdictional claims in published maps and institutional affiliations.

Received: 10 May 2018 Accepted: 29 November 2018

Published online: 19 December 2018

\section{References}

1. Hilary K, Aubert RE, Herman WH (1998) Global burden of diabetes, 1995-2025. Diabetes Care 21:1414-1431

2. Seftel AD, Sun P, Swindle R (2004) The prevalence of hypertension, hyperlipidemia, diabetes mellitus and depression in men with erectile dysfunction. J Urol 171:2341-2345

3. Gonzalez C, Giorgini D, De Loredo L et al (2004) Prevalence of diabetes, obesity, hypertension and hyperlipidemia in the central area of Argentina. Diabetes Metab 30:335-339

4. Saini V (2010) Molecular mechanisms of insulin resistance in type 2 diabetes mellitus. World J Diabetes 1:68-75

5. Scheen AJ (2010) Pathophysiology of type 2 diabetes. Acta Clin Belg 58:335-341

6. Berger J, Moller DE (2002) The mechanisms of action of PPARs. Annu Rev Med 53:409-435

7. Moreno M, Lombardi A, Silvestri E et al (2010) PPARs: nuclear receptors controlled by, and controlling, nutrient handling through nuclear and cytosolic signaling. PPAR Res 2010:1-10

8. Krey G, Braissant O, Horset FL et al (1997) Hypolipidemic agents identified as ligands of peroxisome proliferator- activated receptors by coactivatordependent receptor ligand assay. Mol Endocrinol 11:779-791

9. Heald M, Cawthorne MA (2011) Dual acting and pan-PPAR activators as potential anti-diabetic therapies. Handb Exp Pharmacol 203:35-52
10. Bastaki S (2005) Diabetes mellitus and its treatment. Int J Diabetes Metab 13:111-134

11. Gourgari E, Wilhelm EE, Hassanzadeh $\mathrm{H}$ et al (2017) A comprehensive review of the FDA-approved labels of diabetes drugs: indications, safety, and emerging cardiovascular safety data. J Diabetes Complications 31:1719-1727

12. Wysowski DK, Armstrong G, Governale L (2003) Rapid increase in the use of oral antidiabetic drugs in the United States, 1990-2001. Diabetes Care 26:1852-1855

13. Fiévet C, Fruchart J-C, Staels B (2006) PPAR a and PPAR $y$ dual agonists for the treatment of type 2 diabetes and the metabolic syndrome. Curr Opin Pharmacol 06:606-614

14. Nesto RW, Bell D, Bonow RO et al (2003) Thiazolidinedione use, fluid retention, and congestive heart failure. Circulation 108:2941-2948

15. Munigoti SP, Harinarayan CV (2014) Role of Glitazars in atherogenic dyslipidemia and diabetes: two birds with one stone? Indian J Endocrinol Metab 18:283-288

16. Mandal SP, Mithuna M, Garg A et al (2016) Novel rhodanines with anticancer activity: design, synthesis and CoMSIA study. RSC Adv 6:58641-58653

17. Kulkarni SS, Gediya LK, Kulkarni VM (1999) Three-dimensional quantitative structure activity relationships (3-D-QSAR) of antihyperglycemic agents. Bioorg Med Chem 7:1475-1485

18. Cavender MA, Lincoff AM (2010) Therapeutic potential of aleglitazar, a new dual PPAR- $a / y$ agonist implications for cardiovascular disease in patients with diabetes mellitus. Am J Cardiovasc Drugs 10:209-216

19. Taylor SD, Hill B (2004) Recent advances in protein tyrosine phosphatase 1B inhibitors. Expert Opin Investig Drugs 13:199-214

20. Bialy L, Waldmann H (2005) Inhibitors of protein tyrosine phosphatases: next-generation drugs? Angew Chem Int Ed 44:3814-3839

21. Barr AJ (2010) Protein tyrosine phosphatases as drug targets: strategies and challenges of inhibitor development. Future Med Chem 2:1563-1576

22. Yang S (2010) Pharmacophore modeling and applications in drug discovery: challenges and recent advances. Drug Discov Today 15:444-450

23. Li R, Wang Y, Wang $Q$ et al (2015) In silico design of human IMPDH inhibitors using pharmacophore mapping and molecular docking approaches. Comput Math Methods Med 2015:1-11

24. Goto J, Kataoka R, Hirayama N (2004) Ph4Dock: pharmacophore-based protein-ligand docking. J Med Chem 47:6804-6811

25. Kitchen DB, Decornez H, Furr JR, Bajorath J (2004) Docking and scoring in virtual screening for drug discovery: methods and applications. Drug Discov 3:935-949

26. Lindahl $E$, Hess B, van der Spoel D (2001) GROMACS 3.0: a package for molecular simulation and trajectory analysis. J Mol Model 7:306-317

27. Van Der Spoel D, Lindahl E, Hess B et al (2005) GROMACS: fast, flexible, and free. J Comput Chem 26:1701-1718

28. Zubrys A, Siebenmann CO (1954) Antituberculous isonicotinylhydrazones of low toxicity. Can J Chem 33:11-14

29. Shah SN, Baseer MA (2012) Synthesis and antimicrobial studies of some novel schiff bases. Asian J Pharm Clin Res 5:228-232

30. Hazeldine ST, Polin L, Kushner J et al (2001) Design, synthesis, and biological evaluation of analogues of the antitumor agent, 2- 4- [(7-Chloro2-quinoxalinyl) oxy] phenoxy propionic acid (XK469). J Med Chem 44:1758-1776

31. Mokale SN, Shete MT, Shaikh SI, Shinde DB (2012) Synthesis and hypolipidemic activity of novel 2-(4-(2-amino-6-(4-substituted phenyl) pyrimidin4-yl)-2-substituted phenoxy) acetic acid derivatives. Chem Biol Drug Des 79:548-552

32. Uddin MN, Chowdhury DA, Rony MM (2014) Complexes of Schiff bases derived from 2-hydroxyaldehyde and propane-1,2-diamine: synthesis, characterization and antibacterial screening. Am J Chem Appl 1:12-18

33. Asiri AM, Khan SA (2010) Synthesis and anti-bacterial activities of some novel schiff bases derived from aminophenazone. Molecules 15:6850-6858

34. Asiri AM, Badahdah KO (2007) Synthesis of some new anils: part 1. Reaction of 2-hydroxy-benzaldehyde and 2-hydroxynaphthaldehyde with 2-aminopyridene and 2-aminopyrazine. Molecules 12:1796-1804

35. Iqbal A, Siddiqui HL, Ashraf CM et al (2007) Synthesis, characterization and antibacterial activity of azomethine derivatives derived from 2-formylphenoxyacetic acid. Molecules 12:245-254 
36. Das MS, Devi G (2015) In vitro cytotoxicity and glucose uptake activity of fruits of terminalia bellirica in Vero, L-6 and 3T3 cell lines. J Appl Pharm Sci 5:92-95

37. Skehan P, Storeng R, Scudiero D et al (1990) New colorimetric cytotoxicity assay for anticancer-drug screening. J Natl Cancer Inst 82:1 107-1112

38. Yap A, Nishiumi S (2007) Rat L6 myotubes as an in vitro model system to study GLUT4-dependent glucose uptake stimulated by inositol derivatives. Cytotechnology 55:103-108

39. Tafuri SR (1996) Troglitazone enhances differentiation, basal glucose uptake, and GLUT 1 protein levels in 3T3-L1 adipocytes. Endocrinology 137:4706-4712

40. Gupta RN, Pareek A, Suthar M et al (2009) Study of glucose uptake activity of Helicteres isora Linn. fruits in L- 6 cell lines. Int J Diab Dev Ctries 29:170-173

41. Kubinyi H (1997) QSAR and 3D QSAR in drug design, Part 2: applications and problems. DDT 2:538-546

42. Kubinyi H (1997) QSAR and 3D QSAR in drug design, Part 1: methodology. DDT 2:457-467

43. Méndez-Lucio O, Pérez-Villanueva J, Romo-Mancillasa A, Castillo R (2011) 3D-QSAR studies on purine-carbonitriles as cruzain inhibitors: comparative molecular field analysis (COMFA) and comparative molecular similarity indices analysis (CoMSIA). Med Chem Commun 2:1058-1065

44. Tosco P, Stiefl N, Landrum G (2014) Bringing the MMFF force field to the RDKit: implementation and validation. J Cheminform 6:1-4

45. Gasteiger J, Hutchings MG (1983) New empirical-models of substituent polarizability and their application to stabilization effects in positively charged species. Tetrahedron Lett 24:2537-2540

46. Tsai KC, Chen YC, Hsiao NW et al (2010) A comparison of different electrostatic potentials on prediction accuracy in CoMFA and CoMSIA studies. Eur J Med Chem 45:1544-1551

47. Gasteiger J, Marsili M (1980) Iterative partial equalization of orbital electronegativity- a rapid access to atomic charges. Tetrahedron 36:3219-3228

48. Hess B, Kutzner C, Van Der Spoel D, Lindahl E (2008) GROMACS 4: algorithms for highly efficient, load-balanced, and scalable molecular simulation. J Chem Theory Comput 4:435-447
49. Larsson P, Cuendet MA, Hess B, Lindahl E (2010) Implementation of the CHARMM force field in GROMACS: analysis of protein stability effects from correction maps, virtual interaction sites, and water. J Chem Theory Comput 6:459-466

50. Zoete V, Cuendet MA, Grosdidier A, Michielin O (2011) SwissParam: a fast force field generation tool for small organic molecules. J Comput Chem 32:2359-2368

51. Darden T, York D, Pedersen L (1993) Particle mesh Ewald: an N.log(N) method for Ewald sums in large systems. J Chem Phys 98:10089-10092

52. Berendsen HJC, Postma JPM, Van Gunsteren WF, Hermans J (1981) Interaction models for water in relation to protein hydration. Intermol Forces 14:331-342

53. Mark P, Nilsson L (2001) Structure and dynamics of the TIP3P, SPC, and SPC/E water models at 298 K. J Phys Chem A 105:9954-9960

54. Bussi G, Donadio D, Parrinello M (2007) Canonical sampling through velocity rescaling. J Chem Phys 126:014101-014107

55. Nosé S, Klein ML (1983) Constant pressure molecular dynamics for molecular systems. Mol Phys 50:1055-1076

56. Bala V, Chhonker YS, Hashim SR (2010) Synthesis and antimicrobial activity of schiff bases derived from 2-formylphenoxy acetic acid. Asian J Chem 22:3447-3452

57. Sargeant RJ, Paquet MR (1993) Effect of insulin on the rates of synthesis and degradation of GLUT1 and GLUT4 glucose transporters in 3T3-L1 adipocytes. Biochem J 290:913-919

58. Jung KH, Ha E, Kim M et al (2006) Ganoderma lucidum extract stimulates glucose uptake in $\mathrm{L} 6$ rat skeletal muscle cells. Acta Biochem Pol 53:597-601

59. Cramer RD, Bunce JD, Patterson DE, Frank IE (1988) Crossvalidation, bootstrapping, and partial least squares compared with multiple regression in conventional. Quant Struct Act Relat 7:18-25
Ready to submit your research? Choose BMC and benefit from:

- fast, convenient online submission

- thorough peer review by experienced researchers in your field

- rapid publication on acceptance

- support for research data, including large and complex data types

- gold Open Access which fosters wider collaboration and increased citations

- maximum visibility for your research: over 100M website views per year

At BMC, research is always in progress.

Learn more biomedcentral.com/submissions 